\title{
Managing Service Expectations in Online Markets: A Signaling Theory of E-tailer Pricing and Empirical Tests
}

Debanjan Mitra

Department of Marketing

University of Florida

P.O. Box 117155

Gainesville, FL 32611-7155

Phone: 352-2733284

Fax: 352-846-0457

e-mail: deb.mitra@cba.ufl.edu
Scott Fay

Department of Marketing

University of Florida

P.O. Box 117155

Gainesville, FL 32611-7155

Phone: 352-2733268

Fax: 352-846-0457

e-mail: scott.fay@cba.ufl.edu

October 2008

We thank Peter Golder, Joel Huber, Chris Janiszewski, Robert Shoemaker, the editors of the Journal of Retailing Special Issue on "Modeling the Retail Phenomenon", and the three anonymous reviewers for their valuable comments. We also appreciate Juliano Laran for his help in conducting the lab survey. 


\title{
Managing Service Expectations in Online Markets: A Signaling Theory of E-tailer Pricing and Empirical Tests
}

\begin{abstract}
Expectations play a significant role in determining customer perceptions and satisfaction. Accordingly, retailers seek to manage customers' service expectations. However, the tangible signals of service quality that are available to brick-and-mortar retailers (such as location, store appearance, and salespersons' behavior) may not be available in online markets. Using a signaling model, we obtain conditions when Internet retailers (e-tailers) use price to manage their customers' service expectations. In contrast to extant theory, we find that it is possible for either low or high service e-tailers to use price in signaling their service levels. Further, we develop an appropriate deductive test of our theory based on price-ending patterns as an artifact of the signaling process. Based on this test, we find compelling evidence that e-tailers indeed manage service expectations using price. Interestingly, we also find preliminary evidence that suggests customers implicitly associate price-ending patterns with a retailer's expected service level. We discuss several other implications of our findings for researchers and managers.

(Expectations, Internet marketing, Pricing, Price-ending, Signaling, Separating and Pooling Equilibrium, Retailing)
\end{abstract}




\section{INTRODUCTION}

Expectations are broadly defined as "beliefs that a given response will be followed by some event" (Fishbein and Ajzen 1975, p.30). For retailers, service expectations are customers' "pre-purchase beliefs or evaluative beliefs" (Oliver and Winer 1987, p. 470) about their services including "all activities carried out for the purpose of encouraging the conclusion of a transaction" e.g., selection, procurement, assortment, access, display, aesthetics, layout, sales help, empathy, knowledge, trust, assurance, credit, delivery, and returns (European Court of Justice 2005). Given that at least some of these activities are unobserved, customers face an information asymmetry when evaluating a retailer's services. For Internet-only retailers (henceforth, we call them e-tailers), this asymmetry is likely to be even larger because of two reasons. First, "expectations are not as well-formed" in new markets like the Internet (Zeithaml et al. 2002, p. 367). Second, many tangible signals of service commonly used by traditional retailers are unobservable in online markets (Pan and Zinkan 2006). For example, a customer visiting the Toys R' Us store at Times Square in New York City may use the Toys R' Us brand, prime location, large store size, the colorful Ferris wheel, and a courteous welcome as being indicative of high service. The expected service, however, is less apparent if the customer visits an e-tailer such as etoys.com. After all, there are many websites that look similar, sell similar merchandise, boast of similar high service standards, and can easily imitate each other on website content. Additionally, many e-tailers (see Table 1 for examples) are relatively unknown and unable to spend much on branding and advertising. Therefore, price remains a key (and sometimes the only) instrument influencing customers' service expectations of e-tailers.

There is a rich tradition of research on information economics that examines the role of price signals to solve problems arising under asymmetric information (see Rao and Kirmani 2000, for a review). In particular, past literature has examined how firms with high quality products can affect customers'

quality expectations using price. Note that a key assumption is that, in any signaling equilibrium, the firm that offers high-quality products will incur the cost of signaling since customers prefer higher quality products. We amend this framework to fit the retail service context. This is an important and needed 
theoretical contribution for two key reasons. First, more than $80 \%$ of all products in the US are sold by multiple retailers (Boyle 2003). So, why would a retailer engage in costly actions to influence expectations about a product that is also available at other stores? This question is even more relevant for e-tailers because the online environment makes it almost costless for the customer to navigate away to another etailer selling the same product. Therefore, we believe it is more likely that an e-tailer would seek to influence expectations about its service rather than a physical product that it sells (which is identical across stores). Second, we question whether a price signal is necessarily provided by the high service retailer. We offer two reasons why it may be plausible for a low service e-tailer to incur the cost of signaling its true (low) service level: 1) it (i.e., the low service e-tailer) is expected to be less expensive across-the-board, i.e., for different products and over time and, 2) it is easier to satisfy or delight customers when they expect low service. Later, we provide more details about these reasons and their implications on signaling.

In addition to extending signaling theory to include retail service, in general, and signaling by low service retailers, in particular, another key contribution of this paper relates to the empirical testing of our theory in online markets. In this regard, we point out a conceptual challenge for empirically validating a theory of an unobservable variable. For example, many researchers in the quality signaling literature strive to observe quality that cannot be observed, as per theory. Obviously, if quality can be evaluated, it does not remain 'unobservable' and, therefore, needs no signal. We provide a solution to this contradiction by developing and implementing an appropriate deductive test of our theory. Based on that test, we provide empirical evidence consistent with e-tailers signaling both low and high service. In particular, our finding on e-tailers signaling low service fills a void in terms of finding "examples (of firms that) deliberately under-represent the quality of their products or services" (Kopalle and Lehmann 2006, p. 9).

In sum, the objectives of this paper are two-fold: 1) theoretically, to examine conditions when a retailer can use price to either signal high or low service so as to manage customers' service expectations and 2), empirically, to examine whether these conditions exist in online markets. The paper is organized in five sections. First, we review two streams of literature on signaling and online pricing, and propose our 
thesis on service expectation management. Second, we present a signaling model of service expectation management in which price is a credible signal of service. Third, we discuss a scientific way of testing a theory of an unobservable. In this section, we deduce price-ending patterns as an observable artifact of our theory and derive a testable proposition based on price-ending patterns. The fourth section describes the data, estimation, and results of empirical tests on observed price-ending patterns. Finally, we conclude by summarizing the key findings, discussing the implications and providing directions for further research.

\section{CUSTOMER EXPECTATIONS AND E-TAILER PRICES}

As stated in the introduction, unlike traditional retailers (e.g., warehouse clubs, discount stores, department stores), e-tailers are not able to rely on overt characteristics (e.g., wide concrete aisles with high ceilings, unarranged product bins, shopping mall location) to signal their service and influence customers' expectations. Yet, signaling is desirable by e-tailers since many elements of retail service like personnel (e.g., specialized knowledge of merchandise buyers), delivery and returns (e.g., time or hassle involved in shipping or returning), and procurement (e.g., fashion leader or follower) may be either completely unobservable or prohibitively costly to observe, at least in the short term. Even when the past service level of an e-tailer is reported through prior customers' ratings or reviews, such feedback is often subjective (i.e., hard to evaluate), mixed (i.e., high variance), dated (i.e., pertains to past service which may not reflect current performance), endogenous (e.g., the number of users providing feedback is not exogenously determined), or even biased (i.e., created by interested parties, e.g., see Mayzlin 2006). Moreover, for many small and new e-tailers, customer feedback is just not available. Hence, e-tailers are likely to use price to influence customers' service expectation. In this section we relate customers' expectations with e-tailer prices by drawing upon two related streams of research. We start by discussing the literature on prices as signals of product quality. After that, we focus on the specific context of e-tailer pricing. Based on a review of these literatures, we propose our thesis on e-tailers' service expectation management.

\section{Prices as Signals of Product Quality}

There is abundant research on the antecedents and consequences of customers' information 
asymmetry about product quality. Since Kirmani and Rao (2000) provide a comprehensive review, we only briefly describe the gist of this research. The basic premise is that products consist of many attributes that can only be evaluated after consumption. A common setting for such information asymmetry when product quality is fixed and exogenously determined is referred to as adverse selection. Under adverse selection, the key problem of a high product quality seller is to reveal quality using signals that are credible, i.e., that cannot be copied by a low product quality seller. Thus, even though the notion that high price conveys high quality is well-established in the behavioral literature, the signaling literature provides several conditions for the signal to be credible for rational customers. These include the existence of quality-sensitive as well as quality-insensitive buyers, and a sufficient willingness to pay for quality by the quality-sensitive buyers.

However, whether these theoretical conditions hold in practice is unknown since empirical evidence for high prices signaling high product quality is scant. Both Gerstner (1985) and Tellis and Wernerfelt (1987) find such evidence limited only to specific product categories. Note that prices (in most studies) are at the retail level and thus it is not clear whether price is used to signal product quality or the retailers' services. Provided a product's quality is signaled by other non-price variables (like manufacturer brand, advertising, availability, and packaging) and does not vary across retailers, there seems little reason for a retailer to signal it. Moreover, there is no incentive for a retailer to incur a signaling cost for a product that is also available elsewhere. For example, see Table 1 on the price of Nintendo Wii at 40 different e-tailers. These prices include the product as well as an unobserved level of service. There is little reason for an etailer to signal Wii's quality since it is known to customers from many other sources. ${ }^{1}$ Other researchers make consistent observations, albeit, in different research contexts. For example, "for years advertising executives have been warning marketing executives that (price) promotions will destroy their brand's image ... (but) it is not clear that (price) promotions do detract from a brand's customer franchise" (Blattberg and Neslin 1990, p. 465, p. 473). Likewise, Davis, Inman, and McAllister (1992) find the impact of price promotions on customers' brand evaluations to be non-existent. Consequently, we believe retail prices to 
primarily influence service expectations of a retailer rather than quality expectations of a product. Next, we review the online pricing literature to find additional support for this conjecture.

Table 1 here please

\section{Determinants of E-tailer Prices}

Recently, pricing on the Internet has attracted much academic attention. Key themes of this literature have been to explore whether online markets are more competitive and 'friction-less', and whether customers are more price-sensitive in online markets (Baylis and Perloff 2002; Brynjolfsson and Smith 2000; Pan et al. 2001). Many studies compute the dispersion of prices in online markets and compare this dispersion with the level of price dispersion observed in traditional markets. A robust finding is that price dispersion in online markets is "no lower than offline markets" (Ancarani and Shankar 2004, p. 176). Furthermore, other studies find that average prices in online markets are generally lower than traditional markets even when taxes and shipping costs are included and that e-tailers' price adjustments are frequent and significantly smaller than traditional retailers (Brynjolffson and Smith 2000). In general, it seems that though online markets exhibit higher efficiency on some counts, price dispersion is persistent. For example, Ancaroni and Shankar (2002, p. 176) find that among different types of retailers (multi-channel retailers, traditional retailers, and e-tailers) that sell a particular product, "e-tailers have the highest range of prices but the lowest variability." This means that even though the price of a product is similar across most etailers (i.e., low standard deviation), there are a few that set prices at the extremes (i.e., high maximum and low minimum). Similarly, both Baylis and Perloff (2002) and Pan et al. (2002) find that differences in costs alone are not able to explain price dispersion among e-tailers. Why do some e-tailers' prices deviate from the norm? Given that e-tailers sell a bundle of product and service, and the product is identical across different e-tailers, these divergent e-tailers must be using such extreme prices to signal their service. Since these e-tailers are rational, the signal should be resulting in positive net benefits, i.e., over and above the cost of deviating from the profit maximizing norm. Also, other e-tailers cannot be increasing their profits by mimicking them, in which case the extreme pricing strategy will be untenable. In the next section we 
elaborate on this conjecture.

\section{Service Expectation Management}

Based on the above discussion, it is plausible that e-tailers use prices to manage customers' service expectations. For a given product at a common price, customers prefer high service over low service.

Therefore, it is intuitive that high service e-tailers would like to inform customers that they provide superior service. However, drawing upon two independent streams of research in marketing, we argue that sometimes it is worthwhile for a low service e-tailer to inform customers about its service level. First, prior research on retailing has shown that spillover effects of one product on the purchase of another can have a sizeable impact on retailers' pricing strategies. For instance, loss leaders and other price promotions may be used to draw customers into a store so that they buy additional products (Hess and Gerstner 1987, Walters and MacKenzie 1988, Srinivasan et al. 2004, Richards 2007). Similarly, a customer who anticipates that she will be making additional purchases during a shopping trip or future trips may wish to identify the e-tailer who best meets her needs over the entire purchase stream rather than for a single transaction. In that case even, if a retailer offers higher service at the same price for a specific transaction, price-sensitive customers may still prefer the low service retailer. This is because these customers rationally infer that the low service level of a retailer will translate to lower cost and, thereby, lower expected prices of the unknown future basket of products or lower expected future prices of the same product (Glazer 1984). When there are enough of such customers in the product market, an e-tailer can benefit from signaling that it offers low service. ${ }^{2}$

Additionally, a positive impact of low service expectations on future profits could stem from an alternate rationale. Prior research on customer satisfaction suggests that meeting a high or low service expectation level can both lead to satisfaction (Anderson and Sullivan 1993; Bolton and Drew 1991; Bolton and Lemon 1999). In fact, it may even be easier for e-tailers to satisfy or delight customers with low expectations (Rust et al. 1999). For example, recent research on marketing dynamics suggests a "tension between raising expectations to increase acceptance/ trial and lowering expectations to increase 
satisfaction, and hence, future sales" (Kopalle and Lehman 2006, p. 9). Consequently, high service expectations increase the likelihood of purchases by new customers while low service expectations increase the likelihood of satisfaction and, thereby, higher repeat purchase by existing customers (Oliver 1980).

Based on these two rationales, the effect of setting high service expectations is positive for servicesensitive and single-purchase customers. On the other hand, the effect of setting low service expectations is positive for price-sensitive and multiple-purchase customers. Whether a high service or a low service etailer is more profitable depends on the nature of customers and the product market. When customers, on average, seek to shop at e-tailers which provide high service, a high service e-tailer will try to signal customers about its true service level and a low service e-tailer may try to mimic this high service signal. In contrast, when customers prefer low-service outlets, a low service e-tailer will try to signal its true service level to customers while a high service e-tailer may try to mimic. In either case, when mimicking is not viable (i.e., profits cannot be improved), the signal becomes credible. This is the essence of our service expectation management (SEM) thesis. In the next section, we build a model describing how e-tailers influence customers' service expectations using prices as credible signals of either low or high service.

\section{A MODEL OF E-TAILERS' SERVICE EXPECTATION MANAGEMENT USING PRICE}

\section{Model Set-up}

An e-tailer of type $\theta$ offers either low service $(\theta=1)$ or high service $(\theta=H>1)$. An e-tailer of

type $\theta$ has variable per-unit costs of $c_{\theta}{ }^{3}$ We normalize the cost of providing low service to zero $\left(c_{1}=0\right)$ and assume high service is provided at a $\operatorname{cost}$ of $c_{H}$ per unit where $c_{H}>0$. We assume that the e-tailer's service type is not observable to customers. However, allowing for both informed and uninformed customers would not qualitatively affect our key results (see Bagwell and Riordan 1991, for such a model). Let $\theta^{\mathrm{B}}$ represent customers' expectations of the e-tailer's service type. $\theta^{\mathrm{B}}=1$ corresponds to the expectation that the etailer provides low service; $\theta^{\mathrm{B}}=\mathrm{H}$ corresponds to the expectation that it offers high service. The market consists of $M$ heterogeneous customers, each of whom will purchase at most one unit of a product in the 
first period. Customers have utility functions of the form $U=V \theta^{\mathrm{B}}-P$, where $V$ is distributed uniformly between 0 and $M$, and the value of the outside option is normalized to zero. We assume that e-tailers sell equivalent products but offer heterogeneous levels of services. Notice that, for the immediate purchase, controlling for price, customer utility is higher when the product is sold by a high service e-tailer. However, in line with the discussion in the preceding section, we allow for the possibility that expectations of an etailer's service levels may impact future demand. In particular, let $F\left(\theta^{\mathrm{B}}\right)$ be the expected profit from future sales. Normalizing these future profits, let $F\left(\theta^{B}\right)=F$ if $\theta^{B}=1$ and $F\left(\theta^{B}\right)=0 \quad \forall \theta^{B} \neq 1$. Thus, $F$ represents the incremental long-term effect from having customers believe that one has low service costs. By varying F, our model adjusts for the degree to which customers may prefer to shop at an e-tailer with low expected service or one with high expected service. Specifically, F $<0$ represents the case where there is a negative impact on future profits if customers believe one offers low service, and, $\mathrm{F}>0$ represents the case where there is a positive impact on future profits if customers believe one offers low service.

Although our model shares many similarities with previous models where signaling is useful (e.g., Bagwell and Riordian 1991, Milgrom and Roberts 1986, Janssen and Roy 2007), a key difference is that we use the retailing context to allow for the possibility of signaling services as opposed to product quality which, in turn, results in the possible desirability of signaling low service. This happens when $\mathrm{F}>0$, i.e., even when signaling high service may boost immediate sales, it may dampen future demand leading to a lower profit compared to signaling low service. However, note that while our model allows for the current price to signal an e-tailer's service type and its impact on the future profit, we do not constrain the direction of this impact. Therefore, our model is flexible so as to allow an expectation that an e-tailer has low service leading to either an increase or a decrease in future profits and for the magnitude of this impact to vary.

\section{Model Analysis}

Following the long tradition of signaling models (e.g., Milgrom and Roberts 1986, Fudenberg and Tirole 1991, Chu 1993, Simester 1995), we search for a separating equilibrium in which a firm undergoes 
a costly action in order to signal its true service level. While customers cannot observe all of the e-tailer's services, the e-tailer may be able to signal its service through its choice of price. In that case, one option for the e-tailer is to seek a separating equilibrium, if it exists. In a separating equilibrium, the e-tailer's optimal price choice depends on its true service level and thus customers can infer this service by observing the price chosen. We start with the more obvious case when a high service e-tailer sends the signal, which can occur, e.g., when there is a negative impact on future profits if customers believe one offers low service (i.e., $\mathrm{F}<0)$.

$\underline{\text { Separating-Equilibrium - High service E-Tailer Sends a Costly Signal }}$

Let $\Pi\left(\theta, \theta^{\mathrm{B}}, \mathrm{P}\right)$ be the profit earned by an e-tailer whose true service type is $\theta$ and charges a price $P$ which induces beliefs $\theta^{\mathrm{B}}$. From the modeling assumptions above, we have:

$$
\Pi\left(\theta, \theta^{\mathrm{B}}, \mathrm{P}\right)=\left(\mathrm{P}-\mathrm{c}_{\theta}\right)\left(\frac{\mathrm{M} \theta^{\mathrm{B}}-\mathrm{P}}{\mathrm{M} \theta^{\mathrm{B}}}\right)+\mathrm{I}\left(\theta^{\mathrm{B}}\right) \mathrm{F}
$$

where $\mathrm{I}\left(\theta^{\mathrm{B}}\right)$ is an indicator variable such that $\mathrm{I}(1)=1$ and $\mathrm{I}\left(\theta^{\mathrm{B}}\right)=0 \forall \theta^{\mathrm{B}} \neq 1$

First, we derive the conditions for a "H-Signals separating equilibrium." In this equilibrium, a high service e-tailer signals that it offers high service by charging a high price. A separating equilibrium exists only if this signal is credible, i.e., a low service type e-tailer cannot profitably mimic this high price.

Following Bagwell and Riordan (1991) using the intuitive criterion developed by Cho and Kreps (1987), we solve for the "H-Signals separating equilibrium". Let $\mathrm{P}_{\mathrm{L}}^{\mathrm{HS}}$ be the price that maximizes $\Pi(1,1, \mathrm{P})$. Define $\hat{\mathrm{P}}_{\mathrm{L}}$ as the smallest price such that $\Pi(1, \mathrm{H}, \mathrm{P})<\Pi\left(1,1, \mathrm{P}_{\mathrm{L}}^{\mathrm{HS}}\right) \forall \mathrm{P} \geq \hat{\mathrm{P}}_{\mathrm{L}}$ Let $\mathrm{P}_{\mathrm{H}}^{\mathrm{HS}}$ be the price that maximizes $\Pi(H, H, P)$ s.t. $P \geq \hat{P}_{L}$. Using (1), the separating equilibrium prices and the resulting profit are (see Appendix 1 for an algorithm for computing these prices):

$$
\begin{array}{ll}
\mathrm{P}_{\mathrm{L}}^{\mathrm{HS}}=\frac{\mathrm{M}}{2} & \Pi\left(\mathrm{L}, 1, \mathrm{P}_{\mathrm{L}}^{\mathrm{HS}}\right)=\frac{\mathrm{M}}{4}+\mathrm{F} \\
\mathrm{P}_{\mathrm{H}}^{\mathrm{HS}}=\operatorname{Max}\left[\hat{\mathrm{P}}_{\mathrm{L}}, \frac{\mathrm{M} \mathrm{H}+\mathrm{c}_{\mathrm{H}}}{2}\right] & \Pi\left(\mathrm{H}, \mathrm{H}, \mathrm{P}_{\mathrm{H}}^{\mathrm{HS}}\right)=\left(\mathrm{P}_{\mathrm{H}}^{\mathrm{HS}}-\mathrm{c}_{\mathrm{H}}\right) \frac{\mathrm{M} \mathrm{H}-\mathrm{P}_{\mathrm{H}}^{\mathrm{HS}}}{\mathrm{M} \mathrm{H}}
\end{array}
$$




$$
\text { where } \hat{P}_{L}= \begin{cases}\frac{M H+\sqrt{M H(M(H-1)-4 F)}}{2} & \text { if } F<\frac{M(H-1)}{4} \\ \frac{M H-\sqrt{4 F-M H(M(H-1))}}{2} & \text { if } \mathrm{F} \geq \frac{M(H-1)}{4}\end{cases}
$$

Figure 1a illustrates the H-Signals separating equilibrium. The curve labeled " $\Pi(1,1, \mathrm{P})$ " represents the profit to a low service e-tailer if customers believe it offers low service. The maximum profit obtainable under this condition, $\Pi_{\mathrm{LL}}^{\mathrm{MAX}}$, occurs at $\mathrm{P}=\mathrm{P}_{\mathrm{L}}^{\mathrm{HS}}$. " $\Pi(1, \mathrm{H}, \mathrm{P})$ " shows the profit to the low service e-tailer if customers believe it offers high service. For prices in the interval $\mathrm{P}^{\prime} \in\left(\mathrm{P}_{\mathrm{L}}^{\mathrm{HS}}, \hat{\mathrm{P}}_{\mathrm{L}}\right)$, $\Pi\left(1, H, P^{\prime}\right)>\Pi\left(1,1, P_{L}^{H S}\right)$, i.e., the low service e-tailer would benefit from increasing its price from $\mathrm{P}_{\mathrm{L}}^{\mathrm{HS}}$ to P' if such a price would induce customers to believe it has high service. Thus, if a high service e-tailer chooses a price greater than or equal to $\hat{\mathrm{P}}_{\mathrm{L}}$, customers will believe it has high service and a low service etailer does not have an incentive to mimic this price. Therefore, a high service e-tailer chooses the price that maximizes $\Pi(H, H, P)$ subject to $P \geq \hat{P}_{L}$.

Figures 1a-b here please

The prices $\left(\mathrm{P}_{\mathrm{L}}^{\mathrm{HS}}, \mathrm{P}_{\mathrm{H}}^{\mathrm{HS}}\right)$ constitute an equilibrium only if a high service e-tailer would not benefit from deviating to a lower price (and thus inducing the belief that it offers low service). In particular, (2) is a separating equilibrium if and only if $\Pi\left(\mathrm{H}, \mathrm{H}, \mathrm{P}_{\mathrm{H}}^{\mathrm{HS}}\right) \geq \Pi(\mathrm{H}, 1, \mathrm{P}) \forall \mathrm{P}<\hat{\mathrm{P}}_{\mathrm{L}}$. This condition will hold only if the signal of high service is sufficiently valuable, i.e., $\mathrm{H}$ is sufficiently large and/or $\mathrm{F}$ is sufficiently negative.

Next, we consider the less obvious case when a low service e-tailer sends the signal. This can only occur if $\mathrm{F}>0$, i.e., there is a positive impact on future profits if customers believe one offers low service. $\underline{\text { Separating-Equilibrium - Low Service E-Tailer Sends a Costly Signal }}$

In this case while a high service firm is not willing to signal its service level, a low service e-tailer 
may want to signal that it offers low service by charging a low price (when there is a net benefit from inducing low service expectations). Following a similar approach to the one above, we can solve for such a “L-Signals separating equilibrium." Let $\mathrm{P}_{\mathrm{H}}^{\mathrm{LS}}$ be the price that maximizes $\Pi(\mathrm{H}, \mathrm{H}, \mathrm{P})$. Define $\hat{\mathrm{P}}_{\mathrm{H}}$ as the largest price such that $\Pi(\mathrm{H}, 1, \mathrm{P})<\Pi\left(\mathrm{H}, \mathrm{H}, \mathrm{P}_{\mathrm{H}}^{\mathrm{LS}}\right) \forall \mathrm{P} \leq \hat{\mathrm{P}}_{\mathrm{H}}$. Let $\mathrm{P}_{\mathrm{L}}^{\mathrm{LS}}$ be the price that maximizes $\Pi(1,1, \mathrm{P})$ s.t. $\mathrm{P} \leq \hat{\mathrm{P}}_{\mathrm{H}}$. Using (1), the separating equilibrium prices and the resulting profit are (see Appendix 1 for details):

$$
\begin{array}{cc}
\mathrm{P}_{\mathrm{H}}^{\mathrm{LS}}=\frac{\mathrm{MH}+\mathrm{c}_{\mathrm{H}}}{2} & \Pi\left(\mathrm{H}, \mathrm{H}, \mathrm{P}_{\mathrm{H}}^{\mathrm{LS}}\right)=\frac{\left(\mathrm{MH}-\mathrm{c}_{\mathrm{H}}\right)^{2}}{4 \mathrm{MH}} \\
\mathrm{P}_{\mathrm{L}}^{\mathrm{LS}}=\operatorname{Min}\left[\hat{\mathrm{P}}_{\mathrm{H}}, \frac{\mathrm{M}}{2}\right] & \Pi\left(1,1, \mathrm{P}_{\mathrm{L}}^{\mathrm{LS}}\right)=\mathrm{P}_{\mathrm{L}}^{\mathrm{LS}}\left(\frac{\mathrm{M}-\mathrm{P}_{\mathrm{L}}^{\mathrm{LS}}}{\mathrm{M}}\right)+\mathrm{F} \\
\text { where } \hat{\mathrm{P}}_{\mathrm{H}}=\frac{\mathrm{H}\left(\mathrm{M}+\mathrm{c}_{\mathrm{H}}\right)-\sqrt{\mathrm{H}\left[\left(\mathrm{c}_{\mathrm{H}}\right)^{2}(\mathrm{H}-1)+\mathrm{MH}(4 \mathrm{~F}-\mathrm{M}(\mathrm{H}-1))\right]}}{2 \mathrm{H}}
\end{array}
$$

Figure $1 b$ illustrates the L-Signals separating equilibrium. The curve labeled " $\Pi(\mathrm{H}, \mathrm{H}, \mathrm{P})$ " represents the profit to a high service e-tailer if customers believe it offers high service. The maximum profit obtainable under this condition, $\Pi_{\mathrm{HH}}^{\mathrm{MAX}}$, occurs at $\mathrm{P}=\mathrm{P}_{\mathrm{H}}^{\mathrm{LS}}$. " $\Pi(\mathrm{H}, 1, \mathrm{P})$ ” shows the profit to the high service e-tailer if customers believe it offers low service. For prices in the interval $\mathrm{P}^{\prime} \in\left(\hat{\mathrm{P}}_{\mathrm{H}}, \mathrm{P}_{\mathrm{H}}^{\mathrm{LS}}\right)$, $\Pi\left(\mathrm{H}, 1, \mathrm{P}^{\prime}\right)>\Pi\left(\mathrm{H}, \mathrm{H}, \mathrm{P}_{\mathrm{H}}^{\mathrm{LS}}\right)$, i.e., the high service e-tailer would benefit from reducing its price from $\mathrm{P}_{\mathrm{H}}^{\mathrm{LS}}$ to $\mathrm{P}^{\prime}$ if such a price would induce customers to believe it has low service. Thus, if a low service e-tailer chooses a price less than or equal to $\hat{\mathrm{P}}_{\mathrm{H}}$, customers will believe it has low service and a high service etailer does not have an incentive to mimic this price. Therefore, a low service e-tailer chooses the price that maximizes $\Pi(1,1, \mathrm{P})$ subject to $\mathrm{P} \leq \hat{\mathrm{P}}_{\mathrm{H}}$.

The prices $\left(\mathrm{P}_{\mathrm{L}}^{\mathrm{LS}}, \mathrm{P}_{\mathrm{H}}^{\mathrm{LS}}\right)$ form an equilibrium only if a low service firm would not benefit from deviating to a higher price (and thus inducing the belief that it offers high service). In particular, (3) is a 
separating equilibrium if and only if $\Pi\left(1,1, \mathrm{P}_{\mathrm{L}}^{\mathrm{LS}}\right) \geq \Pi(1, \mathrm{H}, \mathrm{P}) \forall \mathrm{P}>\hat{\mathrm{P}}_{\mathrm{H}}$. Note, this condition will hold only if the low service signal is sufficiently valuable, i.e., a sufficiently small $\mathrm{H}$ and a sufficiently large $\mathrm{F}$. $\underline{\text { Pooling Equilibrium }}$

Under incomplete information, there is another possible outcome: a pooling equilibrium. In this case, an e-tailer chooses the same price $\mathrm{P}_{\mathrm{L}}^{\mathrm{P}}=\mathrm{P}_{\mathrm{H}}^{\mathrm{P}}$ regardless of its service and the uninformed customers remain uncertain of whether it has low or high service. For a pooling equilibrium to exist, an e-tailer must willingly choose this price, i.e. a deviation to an alternate price must not increase its profit.

In sum, our thesis on SEM suggests that (i) when the future profit in signaling low service is sufficiently negative, the high service e-tailer uses a high price to separate itself from a low service e-tailer, (ii) when the future profit in signaling low service is sufficiently positive, the low service e-tailer uses a low price to separate itself from a high service e-tailer, and (iii) when conditions necessary for (i) or (ii) do not hold, then both low and high service e-tailer choose a common price that will not identify their service type.

\section{DEVELOPING A TEST OF SERVICE EXPECTATION MANAGEMENT THEORY}

Our theory suggests that e-tailers use price to signal their service and, thereby, manage customers' service expectations. But, since service levels are unobservable, by definition, how can we demonstrate that such signaling occurs in practice? Past empirical research on signaling does not address this inherent contradiction. For example, Kirmani and Rao (2000) provide a list of 17 empirical articles in the signaling literature. Out of these, 9 articles operationalize quality as Consumer Reports' ratings while the remaining 8 articles use perceived quality ratings by customers. In either case, quality is 'observed' easily by either the researchers or the customers, thus compromising a basic tenet of the signaling theory. Nevertheless, it can be argued that quality is not unobservable, per se, but is only costly to observe. We oppose this contention on two grounds. First, the researchers who observed quality (through perusing Consumer Reports or surveying customers) do not seem to have incurred prohibitive costs. Second, if it was just high costs that prevent us from observing quality, rational players in the market would circumvent that problem 
through spreading costs across all customers. For example, measuring vehicle crashworthiness is obviously a costly endeavor. Yet, many public and private agencies (e.g., US's National Highway Traffic Safety Administration, UK's Transport Research Laboratory, Germany's Allgemeiner Deutscher Automobil Club, Japan's National Agency for Automotive Safety) provide information on different crash tests (FrontalImpact, Offset, Side-Impact, Roll-over, and Roadside Hardware) of many automobiles to customers at zero or minimal costs. Therefore, if quality is unobservable, it cannot be just because of high observation cost. Instead, we argue that even though some elements of quality are observable, others are truly unobservable for all, including customers as well as researchers. Not surprisingly, "the empirical literature of price as a signal (of quality) is sparse" (Rao and Kirmani 2000, p. 71).

Therefore, we use an alternative approach for testing our theory of unobservable service. This approach, frequently adopted in the natural science disciplines, uses deductive reasoning to arrive at observable artifacts of the theory, and then test for the existence of those artifacts (Dingle 1938; Hesse 1958; Shugan 2007). For example, in 1843, mathematician John Adams applied Newtonian gravitation (then termed a theory, since it could not be observed outside of earth because of technological limitations) to deduce the existence, mass, position, and orbit of Neptune from perturbations in the observed orbit of Uranus (Littman 2004). Later in 1846, using Adams' deduction, astronomers Johann Galle and Heinrich d'Arrest observed Neptune, providing strong support to the universality of gravitation. More recently, empirical physicists tested the big bang theory on the universe's birth (an unobservable concept, by definition) through deductions about the abundance of deuterium, helium-3, helium-4, and lithium-7 (Boesgaard and Steigman 1985; Copi, Schramm, and Turner 1995). These examples underscore how to meet the two basic requirements of empirical science - observability and testability, in spite of an unobservable theory. Similarly, we need an observable and testable artifact of our theory of unobservable service in order to examine empirical evidence. In the next subsection, we deduce one such artifact of our theory—patterns of price endings, and provide a testable proposition. 


\section{SEM with Price Thresholds}

There is a long tradition of research in retailing that deals with price thresholds in customer demand. Price thresholds refer to abrupt changes in demand at certain price points. There is overwhelming empirical evidence showing price thresholds at 9-ending price points and the resulting behavior of retailers in choosing price-endings (Gabor and Granger 1964; Kalyanam and Shively 1998; Stiving and Winer 1997; Wedel and Leeflang 1998). Researchers have proposed several theories in support of this empirical phenomenon. These include rounding down, left-to-right comparison, limited memory, inattention, and rational expectations (Basu 1997; Brenner and Brenner 1982; Gedenk and Sattler 1999; Schindler and Kirby 1997; Sims 2003; Thomas and Morwitz 2005). Irrespective of the causes behind 9-ending price thresholds, this empirical regularity leads to a kinked demand function with discontinuities between consecutive 9 -ending and 0 -ending price points.

Therefore, we extend the model developed in the previous section to include such a kinked demand function. The objective, as explained earlier, is to deduce an observable implication of our theory. In particular, we revise the customers' utility functions to: $U=V \theta^{\mathrm{B}}-\phi$, where $\phi$ represents a customer's perception of price. We assume prices are restricted to integer values, where $\rho$ is the last digit and $\delta$ is the retailer's price truncating this last digit. For example, a price of 137 would be associated with $\delta=130$ and $\rho=7$. In accordance with this notation, a 9-ending price would be any price such that $\rho=9$. A proportion $\gamma$ of the population perceives the entire price: $\phi=\delta+\rho$. But, $(1-\gamma)$ cognitively constrained customers only consider the truncated price: $\phi=\delta$. All other assumptions remain the same as previously.

The existence of a segment of customers that neglects the last price digit leads to a demand function that is kinked at all 9-ending points since a one unit increase in price from a 9 -ending to a 0 -ending price results in a larger decrease in demand than does a one unit increase in any other region. Figure 2 illustrates the resulting shape of the demand curve and the associated profit function. Note the kinks in the profit functions at each price where $\rho=9$. Thus, when there is complete information, profits are almost 
always maximized at a 9-ending price. The intuition for this is straight-forward. For a standard linear demand curve, at its apex, there is no first order effect from a change in price. However, with a kinked demand curve, there is a first order (negative) effect from increasing a price from a 9 -ending to a 0 -ending (hereafter referred to as the "threshold effect"). Thus, as long as the segment of customers truncating prices is sufficiently large, deviating to the next lower or higher 9-ending price is profitable for the e-tailer. Therefore, given the kinked demand function and completely informed customers, the status-quo or customary price-ending is 9 (Ginzberg 1936).

Figure 2 here please

\section{Price-Endings in Equilibrium}

We now examine the price-endings when customers cannot observe service. In particular, we are interested in the price-endings that occur in the equilibria, paying close attention to those situations when an e-tailer is most likely to deviate from using 9-endings. For this analysis, it is important to notice the shape of the profit function in Figure 2. In particular, note the difference between the kinks in the LHS and the RHS of the curve. On the LHS of the profit function, profits are generally increasing in price, with the magnitude approaching zero as one nears the apex of the profit function. Furthermore, the natural positive effect of price is partially or fully offset by the negative threshold effect (depending on this price point's proximity to the apex of the profit function). On the other hand, on the RHS of the profit function, the natural negative effect of price on profit is accentuated by the threshold effect. Thus, the negative threshold effect at 0 -ending points offsets increases in profit on the LHS and accentuates decreases in profit on the RHS of the profit curve. This leads to differences in the kinks on the two sides of the profit curve (see Figure 2). Provided e-tailers use price to influence customers' service expectations, our thesis is that the differences on the two sides of the profit curve will lead to different price-ending patterns based on whether the separating equilibrium price is on the LHS or RHS. We use this observed artifact to test our theory on unobservable service. 
To see these differences in price-endings, consider Figure 3a which depicts an L-Signals separating equilibrium. On the LHS of $\Pi(H, 1, P)$, the leftmost intersection of a horizontal line at $\Pi_{\mathrm{HH}}^{\mathrm{MAX}}$ is essentially a random variable. Thus, $\hat{\mathrm{P}}_{\mathrm{H}}$ could be characterized by any random price-ending and a signaling low service e-tailer (in a separating equilibrium) is likely to choose either $\hat{\mathrm{P}}_{\mathrm{H}}$ or the next lowest 9ending price that yields higher profits. Now consider Figure 3b which depicts an H-Signals separating equilibrium. In this case, on the RHS of $\Pi(1, H, P)$, the rightmost intersection of a horizontal line at $\Pi_{\mathrm{LL}}^{\mathrm{MAX}}$ is most likely to intersect at one of the downward jumps between a 9-ending price and a 0 -ending price. Therefore, a signaling high service e-tailer is likely to choose a price equal to $\hat{\mathrm{P}}_{\mathrm{L}}$, i.e., a 0 -ending price, if one is far enough from the apex of the $\Pi(\mathrm{H}, \mathrm{H}, \mathrm{P})$. Stiving (2000) provides a similar intuition behind the prevalence of 0 -endings when retail price signal product quality.

Figures 3a-b here please

Now, we examine the price-endings using randomly simulated values of all the parameters of our model. Table 2 gives simulation results for the price-endings of equilibrium prices under both complete and incomplete information. Table 2 is constructed by making 10,000 draws of parameters where $M$ is set equal to $150, \mathrm{H}$ is uniformly distributed between 1 and $1.8, \gamma$ is uniformly distributed between .1 and $.9, \mathrm{~F}$ is uniformly distributed between -20 and 20 , and $c_{H}$ is uniformly distributed between 0 and 70 . "LL" and "HH" represent the full information cases for a low service and a high service e-tailer respectively. "LSignals" gives the results for a signaling low service e-tailer in the L-Signaling separating equilibrium (when one exists). "H-Signals" gives the results for a signaling high service e-tailer. Note that in each of these separating equilibria, a non-signaling e-tailer would employ the full information price.

Table 2 here please

Table 2 shows that the price-endings used by a low service e-tailer signaling its service level are more likely to be random, i.e., less likely to be 9 -ending and very unlikely to be 0 -ending. For example, in 
Table 2, non 9-endings are employed in less than $0.1 \%$ of the trials when there is full information. But in a L-Signals separating equilibrium, a low service e-tailer uses non 9-ending prices in more than $50 \%$ of the trials. This finding reflects our core contribution in terms of signaling by low service e-tailers. In contrast, the price-endings used by a high service e-tailer signaling high service are more likely to be 0 -ending (as found earlier by Stiving 2000). For example, in the H-Signals separating equilibrium, a high service e-tailer uses 0 -endings in more than $15 \%$ of the trials, whereas 0 -endings are used in less than $0.2 \%$ of the trials for all other cases. ${ }^{4}$

These results show that there is an association between price-endings and price levels when etailers manage service expectations through price. In particular, when e-tailers signal low service using lower prices relative to others, these prices are more likely to have random price-endings. In contrast, when e-tailers signal high service using high prices, its prices are more likely to be 0 -ending. To explore this relationship further, we record both the prices and price-endings for a series of 10,000 trials. For each trial, we make a random draw for each of the parameters using the distributions given above. Then, we determine if an L-Signals separating equilibrium exists. If it does, we record the equilibrium prices $\left(\mathrm{P}_{\mathrm{L}}^{\mathrm{LS}}, \mathrm{P}_{\mathrm{H}}^{\mathrm{LS}}\right)$.

Otherwise, we determine if an $\mathrm{H}$-Signals separating equilibrium exists and record the prices $\left(\mathrm{P}_{\mathrm{L}}^{\mathrm{HS}}, \mathrm{P}_{\mathrm{H}}^{\mathrm{HS}}\right)$ if it does. If none of the separating equilibrium exists, we identify the pooling equilibrium price $\left(\mathrm{P}^{\mathrm{P}}\right)$.

Table 3 records the relationship between price levels and price endings when certain retailers use a lower (higher) price to signal lower (higher) service. Therefore, if retailers use price to signal unobserved service, the resulting pattern of relationship between price levels with specific price-endings should be consistent with that in Table 3. Notice that the number of 9-ending prices is lower at both ends of the price spectrum, 0 -endings are most common for the highest price levels, and random-price endings are most common for the lowest price levels.

Table 3 here please 
Table 3 shows that when e-tailers use price to manage service expectations (as proposed by us) and when there are price thresholds at 9-ending prices (as established by prior literature), the resulting pattern of price-endings can be described by the following proposition:

An e-tailer is more likely to use (i) random-endings if its prices are lower relative to other e-tailers and (ii) 0 -endings when its prices are higher relative to other e-tailers.

Next, we describe our data on prices and price-endings used by e-tailers. Using these data we can test the proposition and, thereby, support or falsify our SEM theory.

\section{EMPIRICAL EVIDENCE}

In this section, we describe two price data sets, one at the product level and the other at the e-tailer level. Next, we use these data to examine relative prices and the corresponding price-endings for (i) identical products sold by different e-tailers and (ii) different products sold by different e-tailers. In both cases, we compare the observed price-ending patterns with that of our theoretically derived patterns (given in Table 3). Additionally, we test our proposition directly by examining the observed relationship between relative price level and price-endings. We conclude this section with a discussion of several analyses on the robustness of our findings.

\section{Data}

In the first data set, we collect the comparative prices of identical products in different stores as reported by cnet.com. Cnet.com reviews 29 different product categories and reports the comparative prices of popular brand products (at the model level) at various e-tailers. We collect the comparative prices of up to 5 "Most Popular Products" and/ or "Editor's Top Products" that are available from at least 5 e-tailers for 21 out of the 29 product categories reported by cnet.com. We do not include taxes, shipping and handling charges in the price since these charges vary (i) for different locations, (ii) for different modes of shipping that are not always directly comparable across stores, and (iii) for the total value of the shopping basket. Also, for e-tailers that do not offer free shipping, these charges are often disclosed during the final step of checkout, making it less likely to be a signal. ${ }^{5} \mathrm{We}$ choose popular products since they are more 
likely to be available from multiple e-tailers. We do not include 8 product categories that are usually priced with other complementary products as a bundle. ${ }^{6}$ To be able to compare across products, we (i) choose specific product models, and (ii) use a relative (to the average) transformation of the prices for each of these products. For example, on 06/16/2007, the digital camera model Canon PowerShot SD1000 Digital $E L P H$ was available at 29 different e-tailers for an average price of $\$ 186.25$. The relative price of this item for an e-tailer is the ratio of its own price to the average price across all of the 29 stores. Therefore, for jr.com selling this item at $\$ 176.88$, the relative price is $176.88 / 186.25$ or 0.95 . Overall, this data (referred to as product-level) contain 1544 relative prices and price-endings of 105 different products.

The use of identical products across multiple e-tailers helps us control for the role of product across stores. However, since our theory is at the retailer level, one might argue that the product-level cnet.com data may not necessarily extend to the store. Therefore, we need to compare prices of e-tailers selling multiple products. For doing that, we need to adopt a metric that can reflect the relative price of a store across multiple products, some or all of which are not comparable with other stores. For example, eCOST.com and Overstock.com are both online discount e-tailers of "close-out" and refurbished brandname merchandise. Between them, who has lower price? Note that since the products sold by these two etailers at any given time are not comparable, we cannot compute a relative price index of identical products. Therefore we use the following approach. We argue that the key drivers of a retailer's price are the manufacturer/ supplier price (i.e., cost of goods sold) and overheads (including sales and marketing, R $\& \mathrm{D}$, general and administrative expenses). Assuming that the manufacturer/ supplier price for an identical product is roughly same across stores, an e-tailer's relative price should be reflected in its overheads (\% of sales revenue). For our example, we find that eCOST.com's overhead is $12 \%$ while that for Overstock.com is $27 \%$. Therefore, if ecost.com were to sell products identical to overstock.com, its prices will likely be lower. To further validate our operationalization of store-level relative price, we identify pairs of stores in our dataset selling at least 1 identical product (Coastal Contact and 1-800-contacts, PC Connection and PC Mall, Amazon and Buy.com, Drugstore.com and Vitacost). For each of these, we find the price of the 
identical product to be lower in the store with the lower overhead ratio.

Accordingly, for the second data set, we obtain data on overheads (as a ratio of total revenue) and percent of different price-endings for the top 100 e-tailers listed by Internet Retailer (2007). We choose etailers which (i) are public, i.e., traded in the stock market, (ii) do not have a 'physical' store presence, and (iii) are not the store-front of a manufacturer. We choose public firms to ensure availability of the cost information. We do not use traditional retailers (e.g., Staples, Office Depot) and manufacturer-retailers (e.g., Dell, Sony) since they have many different ways to signal their service apart from price and, hence, less likely to use price to influence customers' service expectations. Using these criteria, we are left with 45 e-tailers. Next, we used the EDGAR database to obtain the overheads of these e-tailers as a percent of total revenue. Also, for each of these 45 e-tailers, we collect a sample of 100 prices (or prices of all products when less than 100 products are available) using the following multistage random sampling procedure. We select one category in the initial menu using a table of random numbers. We proceed in this manner for each subsequent menu until we reach a page exhibiting products and prices. We select a maximum of 10 different prices from each page and then return to the main menu to start the process again until we reach a total of 100 prices for each e-tailer. In cases where an e-tailer sells less than 100 products, we collect prices of all of their products. We categorize each price as 9-ending, 0 -ending, or random-ending. In the next section, we describe this categorization. Overall, this data (referred to as store-level) contain the incidence of different price-endings for 45 e-tailers and their relative price level as reflected by the overhead ratio.

\section{Definition of price-endings}

There does not appear to be a consensus in the literature about exactly what constitutes a 9-ending price, especially as one begins to consider more expensive items. For example, one definition terms a price as 9-ending only when it ends in 99 cents (Schindler 2001). Another expanded definition includes all prices that end in 9 in the cents position (Stiving and Winer 1997). Still others consider a price as 9-ending if the last dollar digit is 9 (Anderson and Simester 2003). Since we consider a wide variety of products, we must adopt a definition that applies to a wide range of prices. Also, since we consider deviations from 9-ending 
prices, to be conservative we need a relatively more inclusive definition of 9-endings. We consider a price as 9-ending, when it (i) ends in 99 cents, or (ii) is less than $\$ 10$ with a 9 in the cent position, or (iii) is between $\$ 10$ and $\$ 100$ with a 9 in the dime position or (iv) is over $\$ 100$ with a 9 in the rightmost dollar position. Therefore, in addition to $\$ 2.99, \$ 2.49, \$ 24.95$, and $\$ 249.50$ are also categorized as 9 -ending. If a price is not 9-ending, we consider it as 0 -ending if it (i) is less than $\$ 10$ with a 0 in the cent position, or (ii) is less than $\$ 100$ and ends in no cents or (iii) is over $\$ 100$ with a 0 in the rightmost dollar position and no cents. Therefore, $\$ 4.20, \$ 42.00$, and $\$ 140.00$ are all categorized as 0 -ending. If a price is not 9-ending or 0-ending, we categorize it as 'random' ending. Based on this classification, we categorize prices as 9ending, 0 - ending, and 'random'-ending, in each of our two datasets. ${ }^{7}$

\section{Findings}

In Table 4a we report the average use of price-endings for both the product-level and store-level data sets. We find that 9-ending prices are prevalent but not quite "ubiquitous" (e.g., Kalyanam and Shively 1998, p. 16), since a considerable number of other price-endings also exist. Combining both data sets, $25 \%$ of the prices are random-ending, $14 \%$ are 0 -ending, and $62 \%$ are 9 -ending. Is this usage consistent across stores? To answer that question, we examine the distribution of price-endings within each store. Table $4 \mathrm{~b}$ shows that the incidence of random-ending and 0 -ending prices is driven by a small segment of the e-tailers. In particular, 7 out of 45 e-tailers in our data use random-endings for more than $60 \%$ of their products. Similarly, 5 out of 45 e-tailers use 0 -endings for more than $60 \%$ of their products. This is consistent with our theory that predicts such pricing behavior by the signaling e-tailers. Next, we compare the observed relationship between relative price and price-endings with those derived from our theory.

Tables $4 a-b$ here please

\section{$\underline{\text { Relationship between Relative Price and Price-Endings }}$}

Table 5a provides a quintile split of the 1544 relative prices (of 105 different products) in our product-level data along with the frequency of different price-endings. For example, among the lowest quintile of all the 1544 relative prices, $51.78 \%$ are random-ending, $4.85 \%$ are 0 -ending, and the rest 
43.37\% are 9-ending. Among the second lowest quintile $34.30 \%$ are random-ending, $4.21 \%$ are 0 -ending, and the rest $61.49 \%$ are 9 -ending., and so on. Table $5 \mathrm{~b}$ provides the corresponding numbers for the storelevel data. For example, among the cheapest 9 (i.e., the lowest quintile) of the 45 stores, $45.89 \%$ of the prices are random-ending, $6.11 \%$ are 0 -ending, and the rest $48.00 \%$ are 9 -ending. Among the second lowest quintile, $35.56 \%$ of the prices are random-ending, $4.56 \%$ are 0 -ending, and the rest $59.89 \%$ are 9-ending, and so on. In particular, note that the incidence of random-endings decreases while that of 0 -endings increases with relative price in both tables. ${ }^{8}$ Also compare these price-ending patterns with that of the simulated pattern in Table 3 based on our theory. The correlation between all the cells of Table 3 and the corresponding cells in Tables 5a is very high $-0.92(\mathrm{p}<0.001)$. Likewise, the corresponding correlation between Table 3 and Table $5 \mathrm{~b}$ is $0.90(\mathrm{p}<0.001)$. These high correlations indicate that our SEM theory fits the observed relationship between relative prices and price-endings remarkably well. Next, we provide formal tests of our proposition.

\section{Tables 5a-b here please}

\section{Test of Proposition}

First, we use the product-level data. We run binary logistic regressions of the dependent dummy variables 'Random-ending' and '0-ending' with the independent variable 'Relative Price'. The results of these regressions are reported in Table $6 \mathrm{a}$. We find that relative price is significantly negatively related to Random-endings and significantly positively related to 0 -endings ( $p<0.01$ and $p<0.05$, respectively). These results provide strong support for our proposition. Interestingly, the predicted probabilities based on relative price truly distinguish price-endings for almost $70 \%$ of all pairs. This shows that a simple univariate price model is able to explain price-endings across all products in our data set.

Tables 6a-b here please

Next, we consider the store-level data. In Table $6 \mathrm{~b}$, we report the regression results of the percent of random-endings and 0-endings on the relative price level of an e-tailer. As predicted, incidence of random-ending prices in a store is significantly negatively associated with the relative price level of the 
store $(\mathrm{p}<0.001)$. Also, the coefficient for relative price level on the incidence of 0 -ending prices in a store is significantly positive $(\mathrm{p}<0.05)$. Both these associations remain significant in the presence of the other. Remarkably, the incidence of random-endings and 0-endings alone explains more than $30 \%$ of the variance in price level among e-tailers. To further check the predictive power of the price-endings, we classify the etailers in terms of a median split of the relative price level and use a binary logistic regression to identify the e-tailers in the lower median given the price-endings. We find that the incidence of random-ending and 0 -ending prices correctly identifies the lower price e-tailer more than $78 \%$ of the time.

\section{$\underline{\text { Robustness of Findings }}$}

We find that the observed relationship between relative price and price-ending patterns mirrors that of the simulated pattern based on our theory. How robust are our findings to changes in definitions and assumptions? To address that question, we conduct several additional analyses.

First, instead of excluding shipping and handling cost in price (of the product-level data set), we now include it to compute the relative price. To arrive at the shipping cost, we assume the cheapest shipping mode (when there are multiple options), lowest order value (when the shipping prices are based on total order value), and a specific zip-code. 83 out of the 105 products in our original data set are no longer available because of technology obsolescence. Therefore, we collect price and shipping cost of 22 products that are still available with a total of 157 e-tailers. Additionally we collect the same data for 22 other random products available in 241 e-tailers so as to compare whether there is any systematic variation between the two groups of products. For each of the 44 products, we correlate the prices inclusive and exclusive of shipping. For both groups, the correlations are uniformly high ranging between 0.83 and 0.99 . A t-test reveals that there is no difference between the results of the two groups of products $(\mathrm{p}<0.001)$. These high correlations indicate that our results are robust to changes in the way relative price is measured (i.e., including or excluding shipping).

Second, we examine whether our results are sensitive to changes in the operationalization of priceendings. Accordingly, we consider more restrictive definitions of 9-ending, e.g., only prices ending in 99 to 
be 9-endings (Stiving 2001) or all prices ending in 9 in the cent position to be 9-endings (Stiving and Winer 1997). We find that our key results are robust to these changes.

Third, we examine whether our results extend to the price-ending of the shipping-inclusive price. Therefore, we conduct logistic regressions to explain random-endings and zero-endings (in the shippinginclusive price), similar to our analyses reported in Table 6a. We find that the parameters of relative price for the random-ending model remains significantly negative $(\mathrm{p}<0.05)$ and is within one standard error of the parameter reported in Table 6a. The parameter of relative price for the 0 -ending model, however, is nonsignificant though directionally consistent. Based on these results, we believe that the price exclusive of shipping is more likely to contain the service signal than the all-inclusive price.

Fourth, we examine whether our results are robust to the relative price classification. Accordingly, we use splits other than quintiles (5), e.g., quartiles (4) and hexiles (6) to classify relative price level. We find that the similarity between theoretical and observed price-endings (i.e., Tables 3 and 6) remain high irrespective of the type of split.

Overall, the consistency of the results across all these different conditions leads us to believe that our results are fairly robust.

\section{CONCLUSIONS}

In this paper, we theoretically examine conditions when e-tailers, and in particular, low service etailers, can use price to manage customers' service expectations and empirically examine whether these conditions exist in practice. We propose a service expectation management (SEM) theory and find that:

$>$ When the net benefit of setting low service expectations is sufficiently positive, a low service e-tailer will decrease customers' service expectations by signaling its low service level through a price that is lower than its 'normal' profit-maximizing price.

$>$ When the net benefit of setting low service expectations is sufficiently negative, a high service e-tailer will increase customers' service expectations by signaling its high service level through a price that is higher than its 'normal' profit-maximizing price.

Next, following the scientific tradition we argue for an appropriate deductive test of our theory of unobservable service. Specifically, we combine our proposed SEM theory with an empirically well- 
established "9-ending price threshold" demand function. We obtain price-ending patterns in a simulated equilibrium as artifacts of our SEM theory. These patterns reveal the following testable proposition:

$>$ E-tailers with lower relative price are more likely to use random-endings while those with higher relative price are more likely to use 0 -endings.

We test the empirical proposition using (i) a sample of 1544 prices for 105 specific product items available from multiple e-tailers, and (ii) the proportion of different price-endings used by 45 e-tailers.

Based on these data, we find that:

$>$ The correlation between observed patterns of e-tailers' price-endings and simulated price-endings (based on our SEM theory) is significantly high $(\mathrm{p}<0.001)$.

$>$ Random-endings are significantly associated with lower price $(\mathrm{p}<0.01)$ and 0 -endings are significantly associated with higher price $(\mathrm{p}<0.05)$.

In sum, we infer that both low and high service e-tailers behave consistently with our SEM theory, i.e., they use price to manage customers' service expectations.

\section{Managerial Implications}

First, we show it can be rational for some e-tailers to signal low service. While this diverges from the traditional signaling literature which assumes firms are only interested in signaling high quality, it is consistent with many retailing innovations like self-service (i.e., no sales help), wholesale clubs (i.e., barebone warehouse facility), and clearance bins (i.e., unarranged stocks). We view these innovations by "brick and mortar" retailers to be alternate mechanisms of signaling low service to customers while selling popular brands of known quality. The assumption is that customers are able to associate retail prices with retailer service rather than the quality of the products the retailer sells. This idea is also supported by research which finds that price promotions do not negatively impact the perception of national brands in contrast to the dire predictions of the sales promotion literature (Blattberg and Neslin 1990; Davis et al. 1992).

Second, our findings, particularly the one that shows the incidence of random-endings to decrease and incidence of 0 -endings to increase with the level of retail service, may potentially explain many of the 'price-ending' aberrations reported in recent studies. For example, researchers find that (i) lower prices for 
a product are less likely to be 9-ending (Schindler 2001) and (ii) managers believe customers truncate prices but still choose not to use 9-ending prices (Schindler 2003). Notice that our SEM theory is consistent with both of these observations. Our findings also potentially explain anecdotal differences between pricing practices of popular e-tailers. For example, among the top 15 bestsellers of 2007 listed by USA Today, the number of 0-ending prices for Amazon.com is 1 while that of BarnesandNoble.com is 5. Moreover, for these 15 bestsellers, BarnesandNoble.com charges a price that is higher than Amazon.com by $19 \%$ on an average. Based on our SEM theory, we believe this difference in prices (and the resulting pattern of priceendings) may reflect the high service signal of Barnes and Noble.

Third, there have been doubts raised in the past as to how any information conveyed through 'costless' price-endings can be credible, effective, and sustainable over time (Basu 1997; New York Times 2004). We show that in the presence of demand thresholds, specific price-ending patterns are artifacts of retailers' service expectation management. In particular, signaling low service e-tailers are more likely to use random-ending prices, signaling high service e-tailers are more likely to use 0-endings, and all other etailers are likely to use 9-ending prices. As a result, 9-ending prices may have different associations depending on the relative price level of a store. For example, for relatively higher service stores, 9-endings can be associated with a relatively lower price since the full information 9-ending price and the pooling equilibrium 9-ending price are both lower than the separating equilibrium price. In contrast, for relatively lower service stores, 9-endings can be associated with a higher price since the full information 9-ending price and the pooling equilibrium 9-ending price are higher than the separating-equilibrium price. This is contrary to the common belief in the marketing literature that 9-ending prices necessarily signal a low price. To examine this conjecture, we surveyed student subjects about their perceptions of stores for three different profiles of price-endings of different e-tailers - random-endings, 0-endings, and 9-endings. The set of prices for the profiles were carefully chosen such that the mean and variance of the prices were the same. Subjects were explicitly informed that (i) each profile represents a different store, (ii) the prices are randomly drawn from the weekly featured products of these stores, and (iii) though the e-tailers sell similar 
product categories, individual prices across the stores are not for identical products and, therefore, not comparable. They were also informed of a range of services that e-tailers typically provide. Subjects were then asked to predict for each profile the likely service level of the store. 23 out of the 42 subjects chose the random-ending profile to be the most likely to represent the e-tailer with the least service level while the corresponding response for the 9 -ending and 0 -ending profiles were 10 and 7 respectively. This finding, though preliminary, leads us to suspect that price-endings implicitly contain retail service information.

Fourth, we propose and examine a price-based SEM theory. We argue that other avenues of influencing customers' service expectations are limited, at least in the online context. Yet, some non-price possibilities still exist, e.g., shipping \& handling, return policy, and customer feedback. The presence of these alternatives, however, makes our empirical test even more conservative. Also note that these alternatives do not preclude the use of a consistent price signal as a part of a retailer's integrated marketing communication strategy. For example, traditional "brick and mortars" retailers like Wal-Mart and Lowes have many ways to signal service. Yet, they may still be using price to signal low service, as is evident from their random price-ending patterns.

Fifth, our findings on the potential association between price-endings and retail service have important implications for the retail pricing of national brands and, thereby, on the retailers' own private brand strategy. For example, a consistent marketing strategy will entail retailers choosing a quality level of its private brands that conforms to the service level signaled by its national brand pricing.

Finally, a key implication pertains to the effect of price-endings on profitability. For example, WalMart apparently believes that the benefit of the low price signaling 'national brands with low service' outweighs potential gains of more than $\$ 300$ million per annum for switching over to 9-ending prices. ${ }^{9}$ This is in spite of Wal-Mart's key competitors like Target and K-Mart that primarily use 9-ending prices. In view of the size of the potential profit, retailers should conduct more pricing and price-ending experiments.

\section{Directions for future research}

Our study's findings as well as its limitations provide several opportunities for future research. In 
particular, the empirical evidence on price-endings is based on product and store-level prices. The theoretical model, however, shows the extent of 9-endings also depends on several customer and marketlevel variables. These include the percent of customers truncating price, and more importantly, the extent of the incremental benefit of increasing versus lowering customer expectations. For example, our model suggests that e-tailers at either end of the service spectrum will become even less likely to employ 9-endings as more customers consider the full price (see Appendix 2; also see Basu 2006). Future research can hypothesize on additional customer-level variables. Also, empirical tests can be conducted through controlled laboratory experiments or by examining price-endings among (i) different product categories, (ii) different channels of distribution, and (iii) different countries and cultures. Thus, a common theoretical basis can be developed to explain the differences in the usage of price-endings in different contexts as reported in various studies (Lambert 1975; Ratfai 2003; Suri et al. 2004; Van Raaij and Van Rijen 2003). Finally, in spite of the empirical evidence, we still believe our results to be tentative. After all, scientific theories can only be falsified and not be proven true (Popper 2002). Therefore, future research should replicate our study in different service and market contexts as well as deduce other observable implications to arrive at a more robust theory of price signaling. For example, a switchover of currency (such as the change to 'Euro' in European markets or currency rescaling in Turkey) might serve as a natural experiment to see if, and how quickly, credible signaling is re-established. 
Table 1

\section{E-tailer Prices of Nintendo Wii Console}

\begin{tabular}{|c|c|c|}
\hline 1 & AroundTownMarket.com & $\$ 249.83$ \\
\hline 2 & ThisThatandEverythin... & $\$ 258.30$ \\
\hline 3 & GamesComplete.com & $\$ 258.63$ \\
\hline 4 & Sureneeds & $\$ 259.47$ \\
\hline 5 & SHENTECH.COM & $\$ 262.00$ \\
\hline 6 & Computers4SURE & $\$ 266.95$ \\
\hline 7 & Origanime.com & $\$ 267.85$ \\
\hline 8 & eCOST.com & $\$ 268.99$ \\
\hline 9 & DDRUniverse & $\$ 269.00$ \\
\hline 10 & NextDayPC.com & $\$ 269.66$ \\
\hline 11 & ThriftyGadgets.com & $\$ 269.99$ \\
\hline 12 & CompSource & $\$ 273.00$ \\
\hline 13 & TrioInternational.co... & $\$ 280.03$ \\
\hline 14 & Tyrell Electronics.c... & $\$ 286.23$ \\
\hline 15 & http://www.renchi.co... & $\$ 289.90$ \\
\hline 16 & BuyDonlin & $\$ 293.91$ \\
\hline 17 & MobilePlanet, Inc. & $\$ 294.95$ \\
\hline 18 & GameBaz Video Game S... & $\$ 299.40$ \\
\hline 19 & Academic Superstore & $\$ 299.95$ \\
\hline 20 & Elite-Electronix(E2) & $\$ 299.95$ \\
\hline 21 & Elite-Electronix(E2) & $\$ 299.95$ \\
\hline 22 & noqst & $\$ 299.97$ \\
\hline 23 & YesAsia.com & $\$ 299.99$ \\
\hline 24 & HKToyz.com & $\$ 299.99$ \\
\hline 25 & Pro Home Shop & $\$ 299.99$ \\
\hline 26 & oemsat & $\$ 299.99$ \\
\hline 27 & ProdFinds & $\$ 300.00$ \\
\hline 28 & oemsat@dns4ever.com & $\$ 300.00$ \\
\hline 29 & Bargains Plus & $\$ 309.00$ \\
\hline 30 & North Shore Style & $\$ 339.00$ \\
\hline 31 & NCSX & $\$ 345.00$ \\
\hline 32 & VideoGameAction.com & $\$ 349.89$ \\
\hline 33 & vFlyer Inc. & $\$ 350.00$ \\
\hline 34 & BidzTrade.com & $\$ 375.00$ \\
\hline 35 & Curious Minds, LLC & $\$ 389.95$ \\
\hline 36 & CompUPlus.com & $\$ 389.99$ \\
\hline 37 & AverestStore & $\$ 390.00$ \\
\hline 38 & ACE Photo \& Digital & $\$ 394.99$ \\
\hline 39 & SHOP.COM & $\$ 397.99$ \\
\hline 40 & Equistarr Internet $\mathrm{O} \ldots$ & $\$ 399.99$ \\
\hline
\end{tabular}


Table 2

Simulated Price-Endings under Complete and Incomplete Information ${ }^{\text {a }}$

\begin{tabular}{|c|c|c|c|c|}
\hline Price-Ending & LL & HH & L-Signals & H-Signals \\
\hline $\mathbf{0}$ & $0 \%$ & $0 \%$ & $.20 \%$ & $16.24 \%$ \\
\hline $\mathbf{1}$ & 0 & 0 & 1.20 & 2.04 \\
\hline $\mathbf{2}$ & 0 & 0 & 2.00 & 2.33 \\
\hline $\mathbf{3}$ & 0 & 0 & 3.36 & 2.30 \\
\hline $\mathbf{4}$ & 0 & 0 & 6.02 & 2.27 \\
\hline $\mathbf{5}$ & 0 & 0 & 7.45 & 2.71 \\
\hline $\mathbf{6}$ & 0 & 0 & 8.05 & 2.59 \\
\hline $\mathbf{7}$ & 0 & .04 & 9.74 & 1.96 \\
\hline $\mathbf{8}$ & 0 & .09 & 12.27 & 2.82 \\
\hline $\mathbf{9}$ & 100 & 99.87 & 49.73 & 64.73 \\
\hline
\end{tabular}

${ }^{a}$ Values for $H, c_{H}, \gamma$ and $\mathrm{F}$ are drawn randomly, with 10000 sets drawn. For each draw, we find (i) the price-ending under full information (labeled "LL" and "HH"), (ii) the price-ending for a low service e-tailer if a L-Signals separating equilibrium (labeled "L-Signals") exists, and (iii) the priceending for a high service e-tailer if a H-Signals separating equilibrium (labeled "H-Signals") exists. The frequency of each ending is tabulated across all draws and reported as a percentage of draws.

Table 3

Simulated Relative Price Level and Price-Endings

\begin{tabular}{|l|c|c|c|}
\hline \multirow{2}{*}{ Relative Price Level } & Random-Endings & 0-Endings & 9-Endings \\
\cline { 2 - 4 } & $\%$ & $\%$ & $\%$ \\
\hline Lowest Quintile & 38.15 & 0.13 & 61.73 \\
\hline Second Lowest Quintile & 0.00 & 0.00 & 100.00 \\
\hline Middle Quintile & 0.15 & 0.00 & 99.85 \\
\hline Second Highest Quintile & 1.95 & 0.50 & 97.55 \\
\hline Highest Quintile & 14.60 & 12.88 & 72.53 \\
\hline AVERAGE & $\mathbf{1 0 . 9 7}$ & $\mathbf{2 . 7 0}$ & $\mathbf{8 6 . 3 3}$ \\
\hline
\end{tabular}


Table 4a

Share of Price-Endings ${ }^{a}$

\begin{tabular}{|l|c|c|}
\hline \% Share of Price-Endings & $\begin{array}{c}\text { Avg. Product } \\
\text { (cnet.com data) }\end{array}$ & $\begin{array}{c}\text { Avg. Store } \\
(\text { EDGAR data) }\end{array}$ \\
\hline Random-endings & $30.31(18.28)$ & $19.58(26.54)$ \\
\hline 0-endings & $10.75(10.31)$ & $17.02(27.89)$ \\
\hline 9-endings & $58.94(18.16)$ & $63.40(33.20)$ \\
\hline
\end{tabular}

${ }^{\mathrm{a}}$ Standard deviation in parentheses.

Table 4b

Distribution of different price-endings within stores

\begin{tabular}{|l|c|c|c|}
\hline & \multicolumn{3}{|c|}{ No. of stores } \\
\hline \% Distribution of Price-Endings & $\begin{array}{c}\text { Random- } \\
\text { endings }\end{array}$ & 0-endings & 9-endings \\
\hline $0 \%$ to $<20 \%$ & 31 & 36 & 7 \\
\hline $20 \%$ to $<40 \%$ & 5 & 4 & 6 \\
\hline $40 \%$ to $<60 \%$ & 2 & 0 & 3 \\
\hline $60 \%$ to $<80 \%$ & 5 & 2 & 9 \\
\hline $80 \%$ and over & 2 & 3 & 20 \\
\hline
\end{tabular}


Table 5a

Observed Relative Price Level (Product) and Price-Endings

\begin{tabular}{|l|c|c|c|}
\hline \multirow{2}{*}{$\begin{array}{l}\text { Relative Price Level } \\
\text { Product) }\end{array}$} & Random-Endings & 0-Endings & 9-Endings \\
\cline { 2 - 4 } & $\%$ & $\%$ & $\%$ \\
\hline Lowest Quintile & 51.78 & 4.85 & 43.37 \\
\hline Second Lowest Quintile & 34.30 & 4.21 & 61.49 \\
\hline Middle Quintile & 25.24 & 9.71 & 65.05 \\
\hline Second Highest Quintile & 19.74 & 9.39 & 70.87 \\
\hline Highest Quintile & 20.45 & 25.65 & 53.90 \\
\hline AVERAGE & $\mathbf{3 0 . 3 1}$ & $\mathbf{1 0 . 7 5}$ & $\mathbf{5 8 . 9 4}$ \\
\hline
\end{tabular}

Table 5b

Observed Relative Price Level (Store) and Price-Endings

\begin{tabular}{|l|c|c|c|}
\hline \multirow{2}{*}{$\begin{array}{l}\text { Relative Price Level } \\
\text { Store) }\end{array}$} & Random-Endings & 0-Endings & 9-Endings \\
\cline { 2 - 4 } & $\%$ & $\%$ & $\%$ \\
\hline Lowest Quintile & 45.89 & 6.11 & 48.00 \\
\hline Second Lowest Quintile & 35.56 & 4.56 & 59.89 \\
\hline Middle Quintile & 2.33 & 18.22 & 79.44 \\
\hline Second Highest Quintile & 9.00 & 26.22 & 64.78 \\
\hline Highest Quintile & 5.11 & 30.01 & 64.88 \\
\hline AVERAGE & $\mathbf{1 9 . 5 8}$ & $\mathbf{1 7 . 0 2}$ & $\mathbf{6 3 . 4 0}$ \\
\hline
\end{tabular}




\section{Table 6a}

Product-level Logistic Regression Results

\begin{tabular}{|l|c|c|}
\hline Variables & Random-ending (R) & 0-ending (Z) \\
\hline Intercept & $2.82^{* * *}$ & $-2.13^{* * *}$ \\
& $(0.41)$ & $(0.62)$ \\
\hline Product & $-4.11^{* * *}$ & $3.83^{* *}$ \\
Relative Price & $(0.61)$ & $(1.90)$ \\
\hline Log Likelihood & -456.32 & -530.75 \\
\hline \% Concordant pairs ${ }^{\mathrm{a}}$ & $72.9 \%$ & $63.1 \%$ \\
\hline
\end{tabular}

$* \mathrm{p} \leq 0.10, * * \mathrm{p} \leq 0.05, * * * \mathrm{p} \leq 0.01$; standard errors in parentheses.

${ }^{a}$ Measure of Association between the Response Variable and Predicted Probabilities

Table 6b

Store-level Regression Results

\begin{tabular}{|l|l|l|l|}
\hline \multirow{2}{*}{ Variables } & \multicolumn{3}{|c|}{ E-tailer Relative Price } \\
\cline { 2 - 4 } & \multicolumn{1}{|c|}{ Model 1 } & \multicolumn{1}{|c|}{ Model 2 } & \multicolumn{1}{c|}{ Model 3 } \\
\hline Intercept & $0.39 * * *$ & $0.32 * * *$ & $0.36 * * *$ \\
& $(0.025)$ & $(0.025)$ & $(0.030)$ \\
\hline \% Random-Ending & $-0.0022 * * *$ & & $-0.0019 * * *$ \\
& $(0.00073)$ & & $(0.00064)$ \\
\hline \% 0-Ending & & $0.0016 * *$ & $0.0013 *$ \\
& & $(0.00080)$ & $(0.00074)$ \\
\hline $\mathrm{R}^{2}$ & \multicolumn{2}{|c|}{$25.2 \%$} & \multicolumn{2}{|c|}{$15.1 \%$} & $30.6 \%$ \\
\hline \multicolumn{2}{|c|}{$* \mathrm{p} \leq 0.10, * * \mathrm{p} \leq 0.05, * * * \mathrm{p} \leq 0.01 ;$ standard errors in parentheses. }
\end{tabular}


Figure 1a

H-Signals Separating Equilibrium

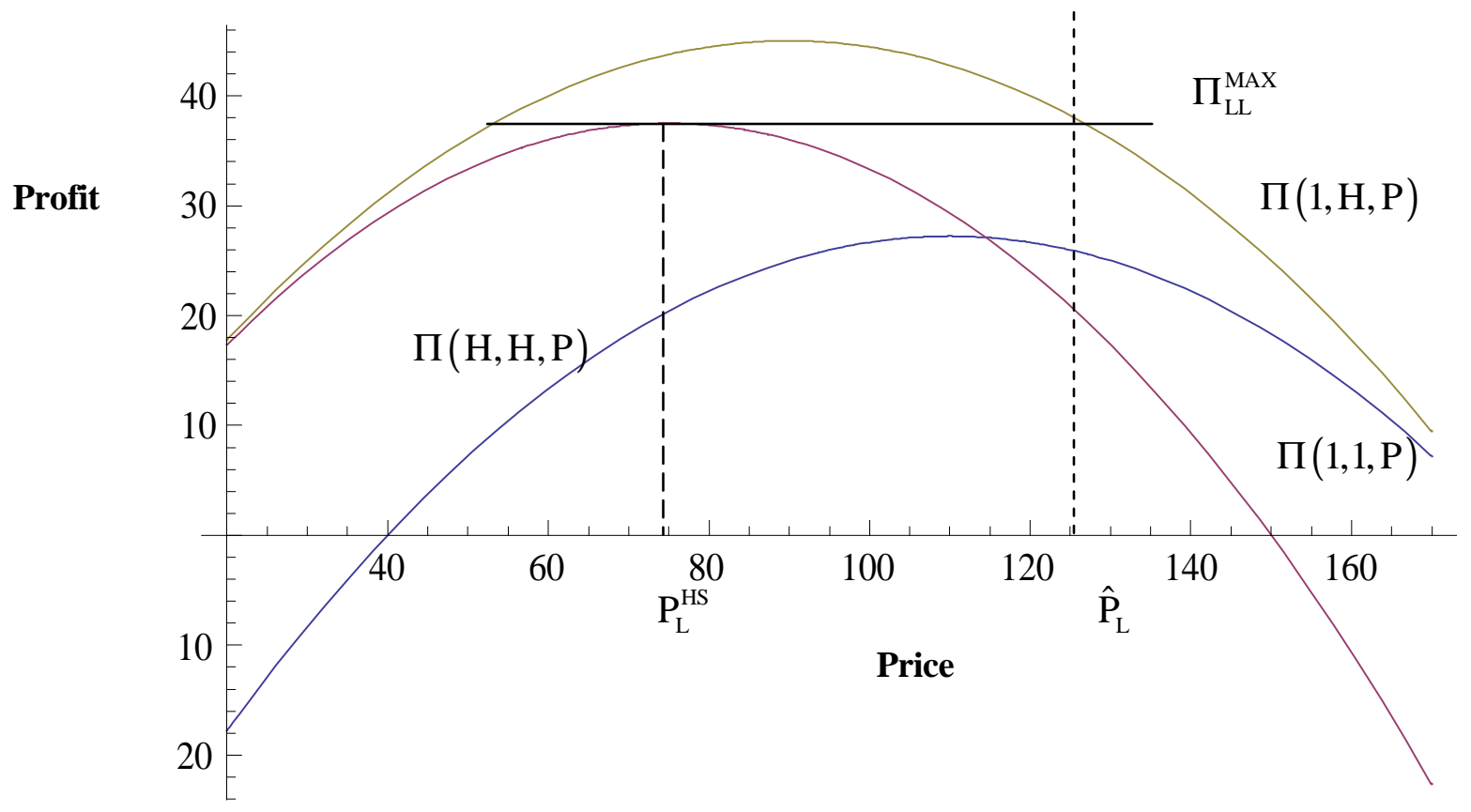

Figure 1b

L-Signals Separating Equilibrium

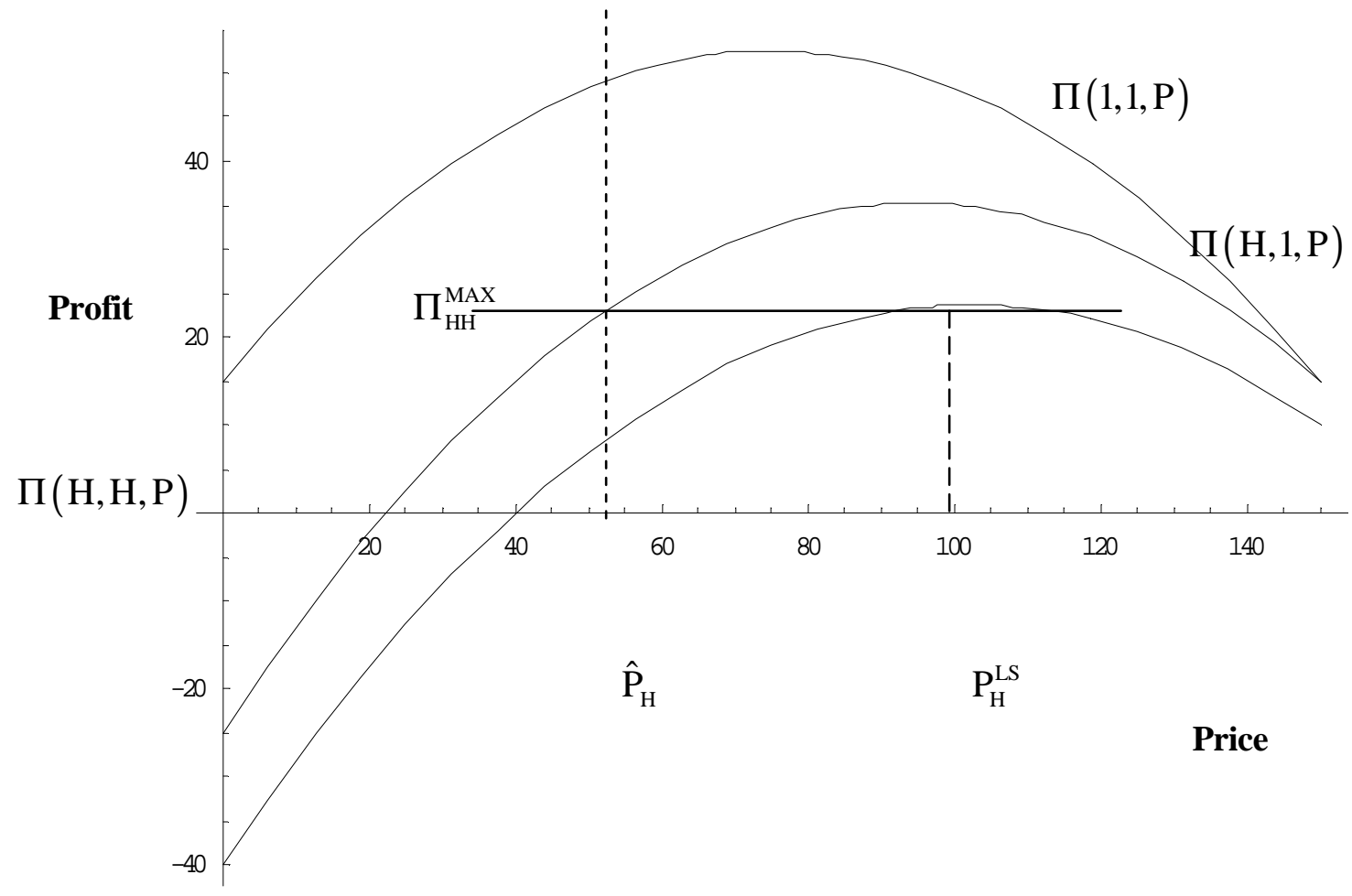


Figure 2

Demand and Profit Functions under Price Thresholds
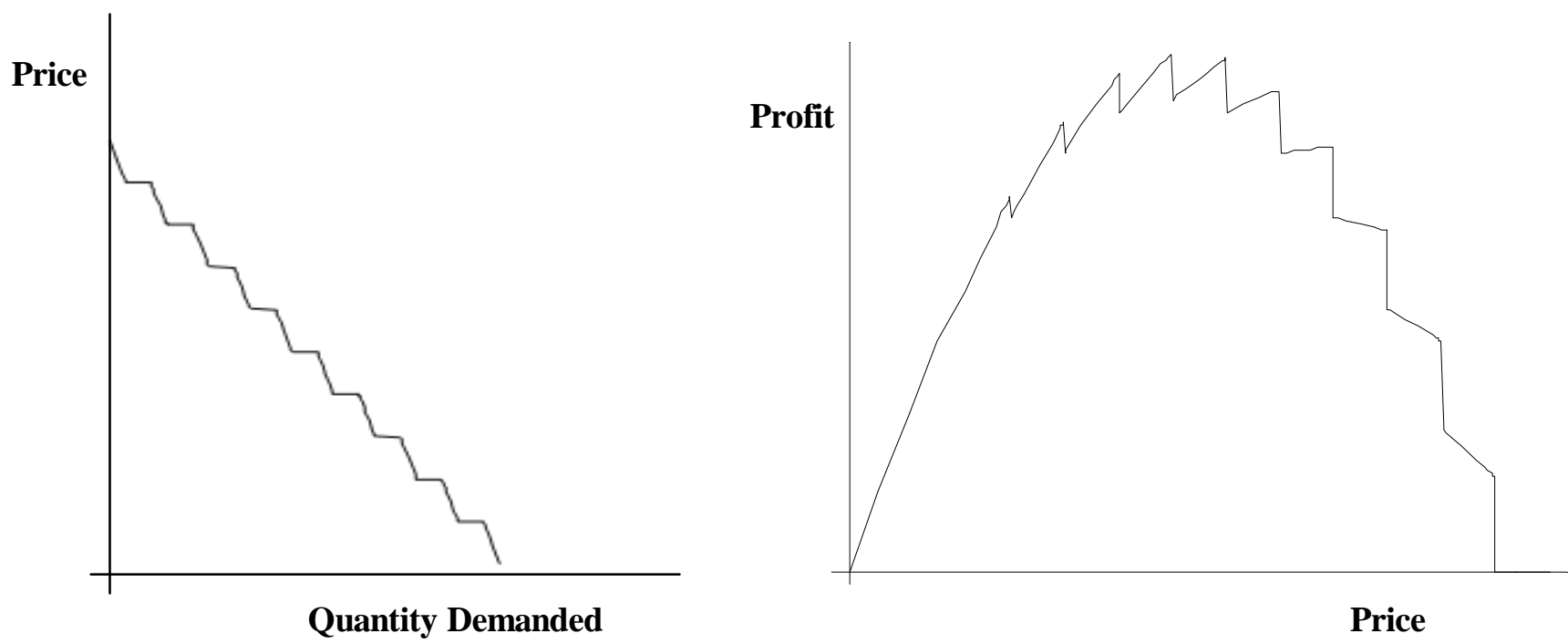
Figure 3a

L-Signals Separating Equilibrium with Price Thresholds

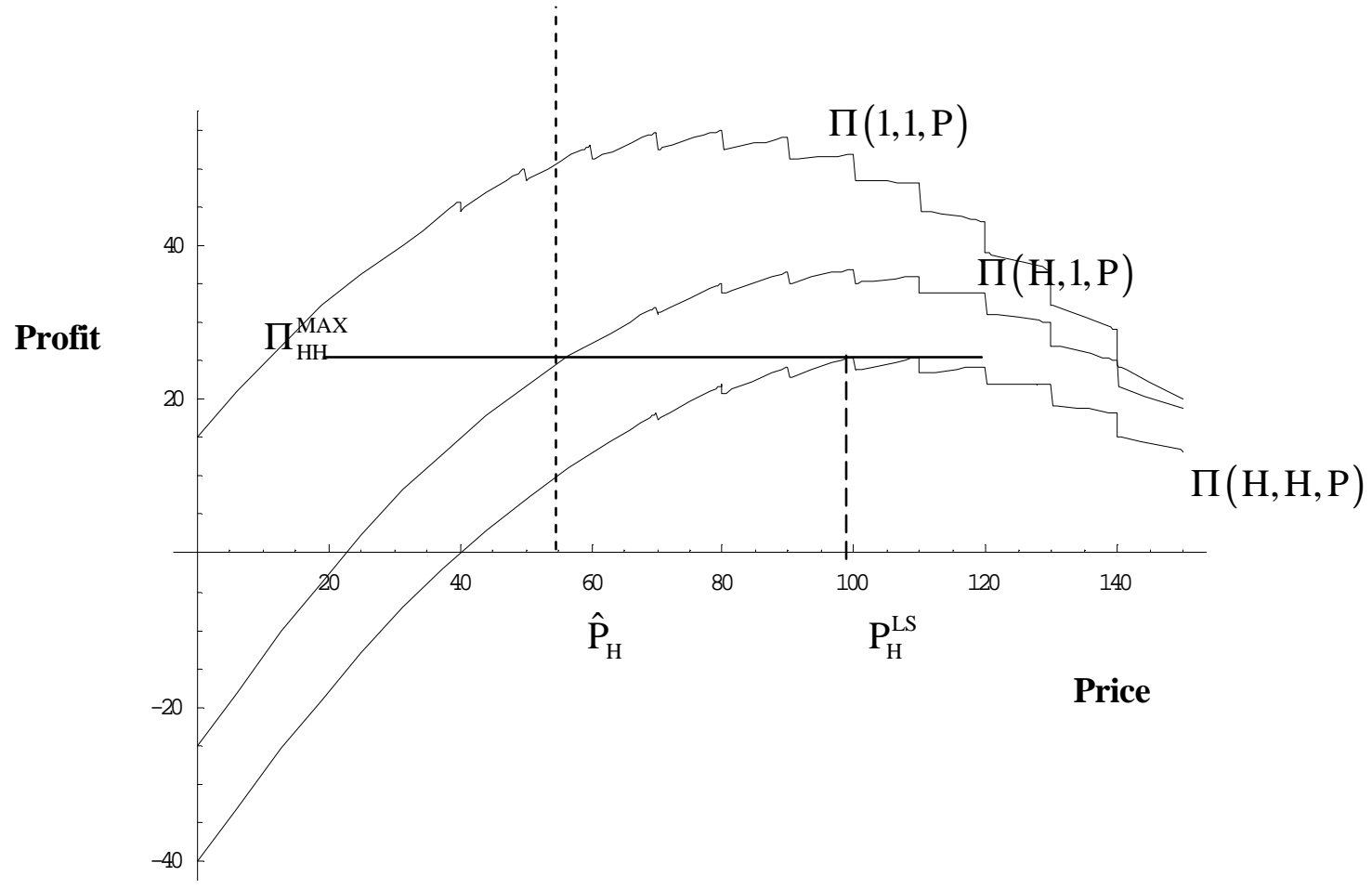

Figure 3b

H-Signals Separating Equilibrium with Price Thresholds

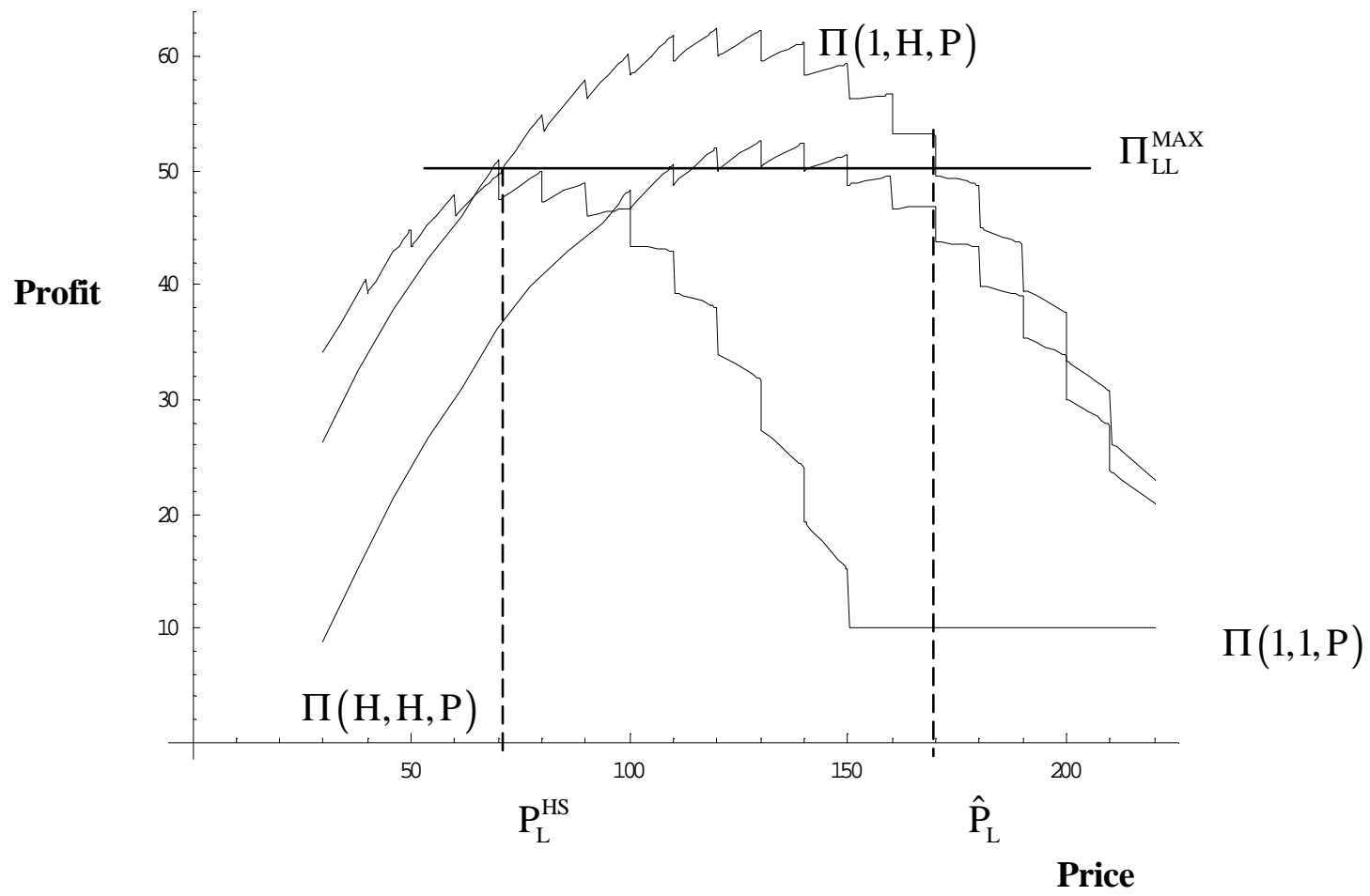




\section{APPENDIX}

\section{Appendix 1: Identifying Separating Equilibria}

We assume prices are restricted to integer values. $\Pi\left(\theta, \theta^{\mathrm{B}}, \mathrm{P}\right)$ is defined as the profit earned by an e-tailer whose true service type is $\theta$ and charges a price $P$ which induces beliefs $\theta^{\mathrm{B}}$ :

$$
\Pi\left(\theta, \theta^{\mathrm{B}}, \mathrm{P}\right)=\left(\mathrm{P}-\mathrm{c}_{\theta}\right) \gamma\left(\frac{\mathrm{M} \theta^{\mathrm{B}}-\mathrm{P}}{\mathrm{M} \theta^{\mathrm{B}}}\right)+\mathrm{I}\left(\theta^{\mathrm{B}}\right) \mathrm{F}
$$

where $\mathrm{I}\left(\theta^{\mathrm{B}}\right)$ is an indicator variable such that $\mathrm{I}(1)=1$ and $\mathrm{I}\left(\theta^{\mathrm{B}}\right)=0 \forall \theta^{\mathrm{B}} \neq 1$

The following algorithms can be used to identity the separating equilibria in which either a high-quality service e-tailer or a low-quality service e-tailer signals its service via its price.

$\underline{\text { Separating-Equilibrium - High-Quality Service E-Tailer Sends a Costly Signal }}$

To find the prices of a low service e-tailer and a high service e-tailer in a H-Signals equilibrium (and to determine if such an equilibrium exists), we follow the following steps:

1. Let $P_{L}^{H S}$ maximize $\Pi(1,1, P)$ and define $\Pi_{L L}^{M A X}$ as this maximum attainable profit.

2. Find the minimum value, $\hat{P}_{L}$ s.t. $\forall P \geq \hat{P}_{L}, \Pi(1, H, P)<\Pi_{L L}^{M A X}$.

3. Calculate $P_{H}^{H S}$ as the price that maximizes $\Pi(H, H, P)$ subject to the restriction that $P \geq \hat{P}_{L}$.

4. If $\Pi\left(H, H, P_{H}^{H S}\right) \geq \Pi(H, 1, P) \forall P<\hat{P}_{L}$, then the prices of $P_{L}^{H S}$ and $P_{H}^{H S}$ constitute a separating equilibrium with profits of $\Pi_{L L}^{M A X}$ for a low service e-tailer and $\Pi\left(H, H, P_{H}^{H S}\right)$ for a high service e-tailer.

$\underline{\text { Separating-Equilibrium - Low-Quality Service E-Tailer Sends a Costly Signal }}$

To find the prices of a low service e-tailer and a high service e-tailer in a L-Signals equilibrium (and to determine if such an equilibrium exists), we follow the following steps:

1. Let $P_{H}^{L S}$ maximize $\Pi(H, H, P)$ and define $\Pi_{H H}^{M A X}$ as this maximum attainable profit.

2. Find the maximum value, $\hat{P}_{H}$ s.t. $\forall P \leq \hat{P}_{H}, \Pi(H, 1, P)<\Pi_{H H}^{M A X}$.

3. Calculate $P_{L}^{L S}$ as the price that maximizes $\Pi(1,1, P)$ subject to the restriction that $\mathrm{P} \leq \hat{P}_{H}$.

4. If $\Pi\left(1,1, P_{L}^{L S}\right) \geq \Pi(1, H, P) \forall P>\hat{P}_{H}$, then the prices of $P_{L}^{L S}$ and $P_{H}^{L S}$ constitute a separating equilibrium with profits of $\Pi\left(1,1, P_{L}^{L S}\right)$ for a low service e-tailer and $\Pi_{H H}^{M A X}$ for a high service etailer.

\section{Appendix 2: 9-endings and customer-level variables}

Table A1 reports the percentage of 9-ending prices used by a low service e-tailer in an L-Signals separating equilibrium and by a high service e-tailer in an $\mathrm{H}$-Signals separating equilibrium (when such equilibria exist). For each data point, we make 10,000 draws holding the proportion of non-truncating customers $(\gamma)$ 
fixed, with the values of all other variables determined randomly using the same distributions as those used to construct Table 3 . For example, when only $10 \%$ of customers do not truncate prices $(\gamma=.1)$, a low service e-tailer will end up employing a 9-ending price in approximately $60.21 \%$ of all simulated trials in which an L-Signals separating equilibrium exists.

Table A1

$\%$ 9-Endings for a Signaling E-Tailer

\begin{tabular}{|l|l|l|}
\hline & \multicolumn{2}{|c|}{ \% of 9-Endings } \\
\hline $\boldsymbol{\gamma}$ & L-Signals & H-Signals \\
\hline 0.1 & $60.21 \%$ & $100 \%$ \\
\hline 0.3 & $55.93 \%$ & $99.25 \%$ \\
\hline 0.5 & $54.44 \%$ & $65.13 \%$ \\
\hline 0.7 & $43.77 \%$ & $34.29 \%$ \\
\hline 0.9 & $28.67 \%$ & $20.28 \%$ \\
\hline
\end{tabular}

Interestingly, even when only a small fraction of customers truncate prices, in the absence of uncertainty about service, it is still almost always optimal to employ 9-ending prices. For example, when only $10 \%$ of customers truncate prices $(\gamma=.9)$, in the full information scenario, we find that a low service e-tailer uses a 9 -ending in nearly $100 \%$ of all simulated trials and that a high service e-tailer uses a 9 -ending in $95.65 \%$ of all simulated trials. 


\section{REFERENCES}

Ancarani, Fabio and Venkatesh Shankar (2004), "Price Levels and Price Dispersion Within and Across Multiple Retailer Types: Further Evidence and Extension," Journal of the Academy of Marketing Science, Vol. 32, No. 2, 176-187.

Anderson, Eric and Duncan I. Simester (2003), "Effects of \$9 Price Endings on Retail Sales: Evidence from Field Experiments," Quantitative Marketing and Economics, 1(1), 93-110.

Anderson, Eugene W. and Mary W. Sullivan (1993), "The Antecedents and Consequences of Customer Satisfaction for Firms," Marketing Science, 12(2), 125-143.

Bagwell, Kyle and Michael H. Riordan (1991), "High and Declining Prices Signal Product Quality," American Economic Review, 81(1), 224-239.

Basu, Kaushik (2006), "Consumer Cognition and Pricing in the 9's in Oligopolistic Markets," Journal of Economics \& Management Strategy, 15(1), 125-141.

(1997), "Why are so many goods priced to end in nine? And why this practice hurts the producers," Economics Letters, 54, 41-44.

Baylis, Kathy and Jeffrey M. Perloff (2002), "Price Dispersion on the Internet: Good Firms and Bad Firms," Review of Industrial Organization, 21(3), 305-324.

Blattberg, Robert C. and Scott Neslin (1990), Sales Promotions: Concepts, Methods and Strategies, Englewood Cliffs, New Jersey: Prentice Hall.

Bolton, Ruth N. and James H. Drew (1991), "Multistage Model of Customers' Assessments of Service Quality and Value," Journal of Consumer Research, 17(4), 375-384.

and Katherine N. Lemon (1999), “A Dynamic Model of Customers' Usage of Services: Usage as an Antecedent and Consequence of Satisfaction," Journal of Marketing Research, 36(2), 171-186.

Boesgaard, Ann Merchant and Gary Steigman (1985), "Big Bang Nucleosynthesis: Theories and Observations," Annual Review of Astronomy and Astrophysics, 23 (September), 319-378.

Boyle, M. (2003), "Brand killers: store brands aren't for losers anymore", Fortune, 148(3), 88-93.

Brenner, Gabrielle A. and Reuven Brenner (1982), "Memory and Markets, or Why Are You Paying \$2.99 for a Widget?" Journal of Business, 55(1), 147-158.

Brynjolfsson, Erik and Michael Smith (2000), "Frictionless Commerce? A Comparison of Internet and Conventional Retailers," Management Science, 46(4), 563-585.

Cho, In-Koo and David M. Kreps (1987), "Signaling Games and Stable Equilibria," The Quarterly Journal of Economics, 102(2), 179-222.

Chu, Wujin (1993), "Demand Signaling and Screening in Channels of Distribution," Marketing Science, 11(Fall), 327-347.

Copi C. J., D. N. Schramm, and M. S. Turner (1995), "Big-bang nucleosynthesis and the baryon density of the universe," Science, Vol. 267(13 January), No. 5195, 192-199.

Davis, Scott, J. Jeffrey Inman, and Leigh McAlister (1992), "Promotion Has a Negative Effect on Brand Evaluations: Or Does It? Additional Disconfirming Evidence, Journal of Marketing Research, 29(1), 143-148.

Dingle, Herbert (1938), "Science and the Unobservable," Nature, Supplement (January 1), 21-28. 
European Court of Justice (2005), Praktiker Bau und Heimverkermärkte AG (Case C-418/02), Newsletters and Bulletins: Registration of Marks for Retail Trade Services in the European Union, May.

Fishbein, Martin and Icek Ajzen (1976), Belief, Attitude, Intention, and Behavior: An Introduction to Theory and Research, Reading, MA: Addison-Wesley.

Fudenberg, Drew and Jean Tirole (1991), Game Theory, MIT Press.

Gabor, Andre and C. W. J. Granger (1964), "Price Sensitivity of the Customer," Journal of Advertising Research, 4(December), 40-44.

Gedenk, Karen and Henrik Sattler (1999), "The Impact of Price Thresholds on Profit Contribution- Should Retailers Set 9-Ending Prices?” Journal of Retailing, 75(1), 33-57.

Gerstener, Eitan (1985), "Do Higher Prices Signal Higher Quality?” Journal of Marketing Research, 22(May), 209-215.

Ginzberg, Eli (1936), “Customary Prices,” The American Economic Review, 26(2), 296.

Glazer, Amihai (1984) “The Client Relationship and a 'Just' Price,” American Economic Review, 74(5) 1089-1095.

Gourville, John T., and Youngme Moon (2004), "Managing Price Expectations through Product Overlap," Journal of Retailing, 80(1) 23-35

Hess, James. D, and Eitan Gerstner (1987) “Loss Leader Pricing and Rain Check Policy,” Marketing Science, 6(4), 358-374.

Hesse, Mary B. (1958), "Theories, Dictionaries, and Observation,” The British Journal for the Philosophy of Science, 9(33, May), 12-28.

Janssen, Maarten C.W. and Santanu Roy (2007), "Signaling Quality Through Prices in an Oligopoly," Working Paper, Erasmus University and Southern Methodist University.

Jing, Bing (2007) "Product Differentiation under Imperfect Information: When Does Offering a Lower Quality Pay?" Quantitative Marketing and Economics 5: 35-61.

Kalyanam, Kirthi and Thomas S. Shively (1998), "Estimating Irregular Pricing Effects: A Stochastic Spline Regression Approach," Journal of Marketing Research, 35(February), 16-29.

Kirmani, Amna and Akshay R. Rao (2000), "No Pain, No Gain: A Critical Review of the Literature on Signaling Unobservable Product Quality," Journal of Marketing, 64(2), 66-79.

Kopalle, Praveen K. Donald R. Lehmann (2006), "Setting Quality Expectations When Entering a Market: What Should the Promise Be?" Marketing Science, 25(1), 8-24.

Lambert, Zarrel V. (1975), "Perceived Prices as Related to Odd and Even Price Endings," Journal of Retailing, 51(3), 13-22.

Littmann, Mark (2004), Planets Beyond: Discovering the Outer Solar System, Courier Dover Publications.

Mayzlin, Dina (2006), “Promotional Chat on the Internet,” Marketing Science, 25(2), 157-165.

Milgrom, Paul and John Roberts (1986), "Price and Advertising Signals of Product Quality," Journal of Political Economy, 94(4), 796-821. 
New York Times (2004), “From the Desk of David Pogue: 99 Cents or a Dollar?” August 19.

Oliver, Richard L. and Russell S. Winer (1987), "A framework for the formation and structure of consumer expectations: review and propositions," Journal of Economic Psychology, 8(4), 469-499.

(1980), "A Cognitive Model of the Antecedents and Consequences of Satisfaction Decisions," Journal of Marketing Research, 17(4), 460-469.

Pan, Xing, Brian T. Ratchford, and Venkatesh Shankar (2002), "Can Price Dispersion in Online Markets be Explained by Differences in E-Tailer Service Quality?" Journal of the Academy of Marketing Science, 30(4), 433-445.

Pan, Yue and George M. Zinkhan (2006), "Determinants of Retail Patronage: A Meta-Analytical Perspective," Journal of Retailing, 82(3), 229-243.

Popper, Karl Raimund (2002), Conjectures and Refutations: The Growth of Scientific Knowledge, Routledge, 2002

Ratfai, Attila (2003), “The Dynamics of Price Points," Working Paper, Central European University, Budapest, Hungary.

Richards, Timothy J. (2007) “A Nested Logit Model of Strategic Promotion," Quantitative Marketing and Economics, 5(1) 63-91.

Rust, Roland T., J. Jeffrey Inman, Jianmin Jia, Anthony J. Zahorik. 1999. What You Don't Know About Customer-Perceived Quality: The Role of Customer Expectation Distributions. Marketing Science. 18 (1), 77-92.

Schindler, Robert M. (2006), "The 99 Price Ending as a Signal of Low-Price Appeal," Journal of Retailing, 82(1), 71-77.

(2001), "Relative Price-Level of 99-Ending Prices: Image versus Reality," Marketing Letters, 12(3), 239-247.

and Patrick N. Kirby (1997), "Patterns of Rightmost Digits Used in Advertised Prices: Implications for Nine-Ending Effects," Journal of Consumer Research, 24 (September), 192-201.

Shoemaker, Robert W., Debanjan Mitra, Yuxin Chen, and Skander Essegaier (2003), "A Comment on: Price Endings When Prices Signal Quality,” Management Science, 49(12), 1753-1758.

Shugan, Steven M. (2007), "It's the Findings, Stupid, Not the Assumptions," Marketing Science, 26(4), 449-459.

Simester, Duncan (1995), "Signaling Price Image Using Advertised Prices,” Marketing Science, 14(2), 166-188.

Sims, Christopher A. (2003), "Implications of Rational Inattention," Journal of Monetary Economics, $50(3), 665-690$.

Srinivasan, Shuba, Koen Pauwels, Dominique M. Hanssens, and Marnik G. Dekimpe (2004), "Do Promotions Benefit Manufacturers, Retailers, or Both?” Management Science, 50(5), 617-629.

Stiving, Mark (2000), "Price-Endings When Prices Signal Quality,” Management Science, 46(12), 16171629.

and Russell S. Winer (1997), "An Empirical Analysis of Price Endings with Scanner Data," Journal of Consumer Research, 24 (June), 57-67. 
Suri, Rajneesh, Rolph E. Anderson, and Vassilli Kotlov (2004), "The Use of 9-Ending Prices: Contrasting United States with Poland," European Journal of Marketing, 38(February), 56-72.

Tellis, Gerard J. and Birger Wernerfelt (1987), "Competitive Price and Quality Under Asymmetric Information," Marketing Science, 6(1), 240-253.

Thomas, Manoj and Vicki Morwitz (2005), "Penny Wise and Pound Foolish: The Left-Digit Effect in Price Cognition," Journal of Consumer Research, 32(1), 54-64.

Van Raiij, W. Fred and Cecile L. A. Van Rijen (2003), "Money Illusion and Euro Pricing," presented at IAREP Workshop on Euro Currency and Symbol, University of Vienna, Austria, July 3-5.

Walters, Rockney G., and Scott B. MacKenzie (1988), "A Structural Equations Analysis of the Impact of Price Promotions on Store Performance," Journal of Marketing Research, 25 (Feb.) 51-63.

Wedel, Michel and Peter S. H. Leeflang (1998), "A Model for the Effects of Psychological Pricing in Gabor-Granger Price Studies,” Journal of Economic Psychology, 19(2), 237-260.

Zeithaml, Valarie A., A. Parasuraman, Arvind Malhotra (2002), "Service quality delivery through Web sites: A critical review of extant knowledge, Journal of the Academy of Marketing Science, 30(4), 362-375. 
${ }^{1}$ However, Gourville and Moon (2004) suggest that pricing of overlapping products can be used to influence the store's overall price image. Such an explanation is consistent with our suggestion that price signals can play an important role in influencing retailer profitability in future periods.

${ }^{2}$ Jing (2007) presents a model in which, due to the high price sensitivity of consumers, a firm that chooses a low product quality will be more profitable in equilibrium than its rival who offers a higher quality product, but less frequent price discounts.

${ }^{3}$ It would be straight-forward to add fixed costs of service to the model. However, since fixed costs do not affect pricing decisions, the key difference across service types is in variable costs.

${ }^{4}$ The prevalence of 0-endings would be larger if we imposed restrictions similar to condition 2 in Stiving (2000). Instead, we follow Shoemaker et al. (2004) and do not exclude the "cheap" separating equilibria, i.e., where the full information solution also serves as a separating equilibrium.

${ }^{5}$ In the robustness section, we provide additional analyses that suggest that including shipping and handling in arriving at the relative prices do not affect our results.

${ }^{6}$ These categories are wi-fi, web hosting, networking, cellular phones, internet access, car tech, DVR, and software.

${ }^{7}$ In the robustness section, we discuss other definitions of 9-endings and their effect on our key results.

${ }^{8}$ In the robustness section, we discuss other types of splits to classify relative price level.

${ }^{9}$ We assume the average price of an item in Wal-Mart to be $\$ 10$ and the average price-ending to be 5 cents. Now if Wal-Mart were to increase all its prices to the next 9-ending cent, the pre-tax profits increase by 4 cents per item. This translates to $\$ 300$ million at the current sales level and about $5 \%$ of its current operating profits. 